\title{
Enhancement of Lateral In-Plane Capacity of Partially Grouted Concrete Masonry Shear Walls
}

\author{
M. Bolhassani ${ }^{1}$; AA. Hamid ${ }^{2}$; FL. Moon ${ }^{3}$
}

Abstract: The goal of the research presented herein is to investigate a new approach to the reinforcement of partially grouted walls, double side-by-side reinforced cells, in order to enhance the seismic performance of such walls. Specifically, the results from the destructive tests of three cantilever full-scale square masonry shear walls are presented. The control wall was constructed using the conventional single cell reinforcement $(\mathrm{SR})$ approach, with the remaining two walls constructed using double cell reinforcement with bond beams (DR), and with the addition of bed-joint reinforcement (DR-JR), respectively. To permit direct comparison, the total amount of reinforcement in the $S R$ and $D R$ walls was held constant. The experimental investigation indicated that the DR reinforcement approach resulted in significantly improved lateral in-plane response compared to the conventional SR approach. Specifically, the DR wall exhibited a $34 \%$ increase in shear capacity and $47 \%$ increase in displacement ductility. To investigate the effect of grouting on the response of proposed reinforcement details a numerical modeling technique was developed based on the infilled-frame concept and calibrated with the experimental behavior of considered walls. It is evident from the results of numerical modeling that response of walls is in a good agreement with the behavior observed in the experiments. Numerical model showed that the behavior of grouted and ungrouted parts of $P G$ walls are similar to a frame and an infilled, respectively. Grouting double side-by-side cells enhances the frame action of grouted masonry parts and also provides a better confinement for the infilled masonry. As a result of the strengthened frame the performance of wall DR was improved significantly compared to wall SR.

1. Ph.D., Candidate, Department of Civil Architectural and Environmental Engineering, Drexel University, Philadelphia, PA, mb3238@drexel.edu.

2. Professor, Department of Civil, Architectural and Environmental Engineering, Drexel University, Philadelphia, PA, hamidaa@drexel.edu.

3. Associate Professor, Department of Civil, Architectural and Environmental Engineering, Drexel University, Philadelphia, PA, flm72@drexel.edu. 
Keywords: Partially grouted masonry shear wall; Single grouted cells; Double grouted cells; Bed-joint reinforcement; Infilled-frame; Numerical modeling.

\section{Introduction}

Masonry is the oldest structural material still in use for a vast variety of contemporary buildings construction. Masonry structures are generally classified as either reinforced (RM) or unreinforced (URM), with RM further classified as either fully grouted $(F G)$ or partially grouted $(P G)$ (i.e. where grout is placed only in cells containing reinforcing steel). Reinforced masonry constitutes about $10 \%$ of all low-rise constructions in the US, and includes mostly commercial and school buildings, with some multi-story hotels, college dormitories and apartment buildings. Partially grouted walls have been favored over FG walls because of ease and speed of construction and economy. The vast majority of reinforced masonry constructions in the mid-western and eastern parts of the US are partially grouted (PG). However, because of relatively limited research, with notable exceptions including [1], [2], [3], [4], [5], [6], [7], [8], [9], [10], [11], and [12] into the behavior of this type of wall, their lateral in-plane behavior, important for seismic actions, is not fully understood.

The amount and distribution of horizontal and vertical reinforcement are effective for improving shear strength and controlling crack development under lateral in-plane loading. When the spacing of vertical reinforcements is relatively close, the behavior of PG will be more similar to FG walls [8]. PG masonry walls showed a poor seismic performance in moderate seismicity areas. Using FRP [13], [14], [15], and [16] or prestressed masonry [17], [18], and [19] are listed as common methods of retrofitting to reduce the vulnerability of existing masonry structures. However, the methods of design need to be revised for the new constructions. One simple and straightforward approach to avoid the unfavorable behavior of PG reinforced masonry walls is to abandon partial grouting and adopt full grouting. While this could be argued for special walls where the reinforcing bars and, therefore, the grouted cells have to be spaced at no more than $1.2 \mathrm{~m}$, it would significantly increase the cost and reduce the efficiency of construction for ordinary masonry walls, and make reinforced masonry much less 
competitive as compared to other construction materials like concrete tilt-up construction. Therefore, design details and methods to improve the performance of these structures must retain the economy and efficiency of construction.

PG walls designed and tested according to current masonry code have shown a poor seismic performance in areas of low to moderate seismicity [5], [8], [20], and [21]. The primary reason for this problem was traced to the assumption of linearly varying flexural strains, which the ungrouted portions of the wall proved unable to enforce. Past studies (e.g. [5] and [8]) have shown that vertically grouted cells in PG walls are vulnerable to shear failure as horizontal shear cracks propagate along bed-joints from the ungrouted masonry into the grouted cells. Regions near the intersection of vertically grouted cells and bond beams are particularly vulnerable to damage due to the interaction between the grouted masonry elements and ungrouted panels. One method to avoid or delay this kind of damage and improve the ductility of a wall is to use double side-by-side reinforced cells instead of single reinforced cells, which is currently used in practice. The vertical reinforcing bars in the double cells can be tied together with hooked tie bars, and this will make the grouted elements behave more like reinforced concrete elements. Since ordinary walls are normally sparsely reinforced and grouted, doubling the grouted cells will only have a small impact on the construction cost and effort.

The goal of the research presented herein is to investigate this new approach to the reinforcement of PG shear walls through adopting an infilled wall model as opposed to the monolithic wall model that currently underpins the current masonry code by comparing the performances of suggested configuration compared with conventional design. The experimental part of the paper focuses on the effect of double grouting cells and bed-joint reinforcement on the lateral in-plane capacity of the PG walls. To explore the effect grouting on the response of proposed wall configuration (doubly grouted) a numerical model using Abaqus [22] has also been developed. 


\section{Experimental program}

\subsection{Material properties of masonry units, assemblages and walls}

Units- Two types of hollow concrete blocks, regular and stretcher, with nominal thickness of $200 \mathrm{~mm}$, meeting ASTM C90 provisions, were used in this research. The average net compressive strength and splitting tensile strength of the units were 20 and 3.2 MPa, confirming to ASTM C140 and C1006, respectively. Fig. 1 shows unit dimensions, compression and splitting tests.
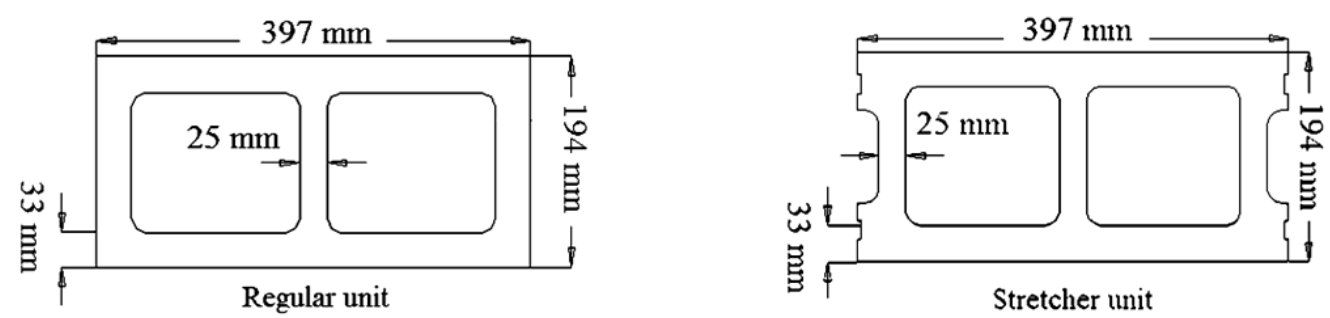

(a) Unit dimensions

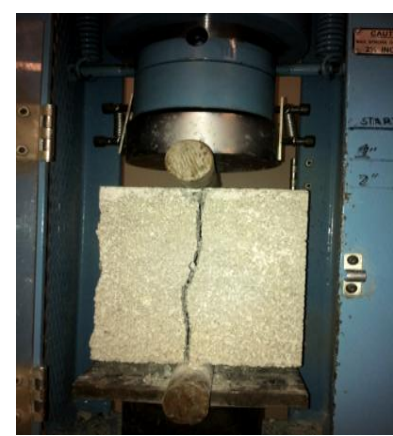

(b) Unit splitting tensile test

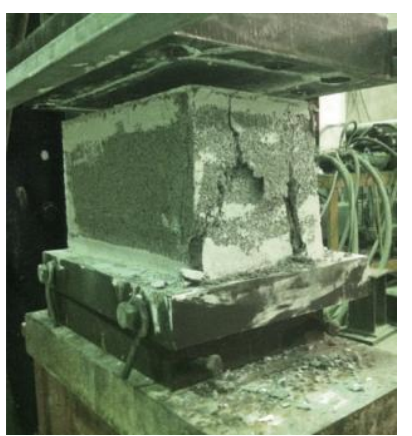

(c) Unit compression test

Fig. 1 Unit configuration and test setups

Assemblages- Three hollow (ungrouted) full blocks wide and two grouted half blocks wide, three courses high, prisms were constructed in stack bond (Fig. 2a). These assemblages were tested under axial compression following ASTM C1314 standard and resulted in an average compressive strength of 15.3 and 25.4 MPa for ungrouted and grouted prisms, respectively. Three pairs of ungrouted and grouted cross specimens were also constructed as shown in Fig. $2 \mathrm{~b}$, to determine bed-joint shear strength. Results show that grouted shear strength was 3 times higher than the ungrouted shear strength. At the end three hollow and fully grouted diagonal tension 
(DT) assemblages with six units height and three units long were built with running bond configuration and tested diagonally following ASTM E519 standard, (Fig. 2c). Grouted DT specimens showed double the diagonal tensile strength of the hollow specimens. The failure mode of the UG specimens was a zigzag joint de-bonding failure (Fig. 3a) whereas for the FG specimens it was a straight line crack passing through the units, grout and mortar joints, see Fig. 3b. Results are summarized in Table 1, more detailed information can be found in [23].

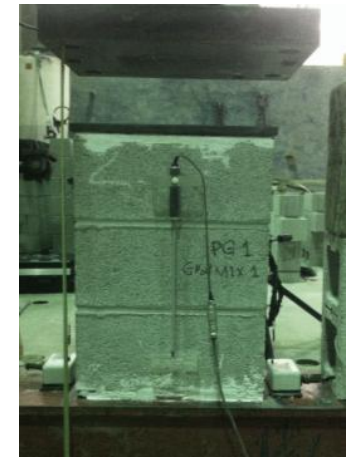

(a) Prism

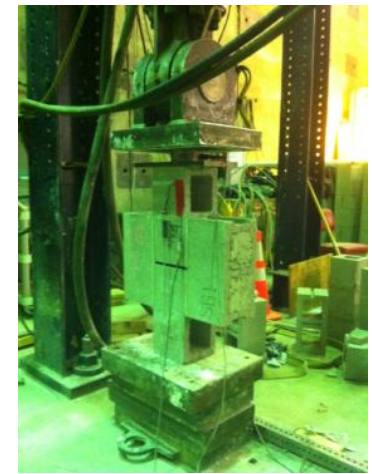

(b) Bed-joint shear

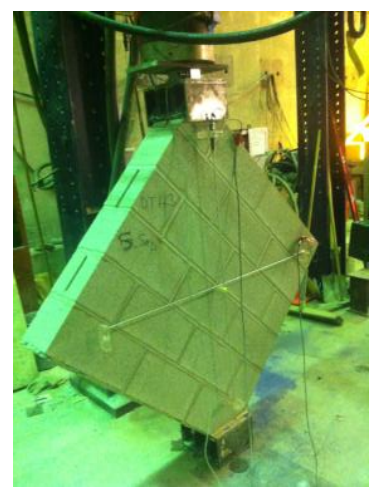

(c) Diagonal tension

Fig. 2 Assemblage tests

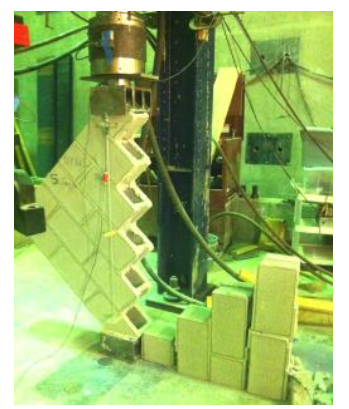

(a) Ungrouted specimen

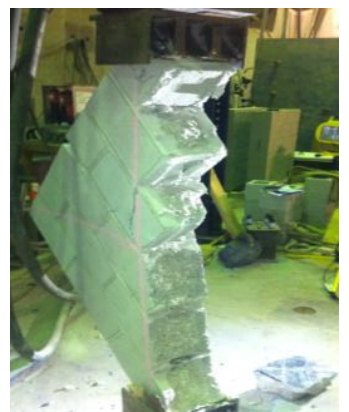

(b) Grouted specimen

Fig. 3 Failure modes of diagonal tension specimens

Mortar and reinforcing bars- In addition to units that mentioned above, Portland cement lime (PCL) mortar type S according to ASTM C270 ingredient proportions with an average 28 days compressive strength of $13 \mathrm{MPa}$ was used in the walls construction. Coarse grout meeting ASTM C476 provisions with an average measured net compressive strength of $23 \mathrm{MPa}$ and $250 \mathrm{~mm}$ slump was used. Two different 
reinforcing bars sizes, D 19 and D 13 meeting ASTM A615 provisions, were used with an average yield strength of $414 \mathrm{MPa}$. For wall DR-JR, standard bed-joint reinforcements, meeting ASTM A951, with $3.7 \mathrm{~mm}$ diameter (9 gauge side rods and 9 gauge cross rod) were used.

Table 1 Assemblages test results

\begin{tabular}{lccc}
\hline \multirow{2}{*}{ Specimen } & \multicolumn{3}{c}{ Strength (MPa) } \\
\cline { 2 - 4 } & Compression & Shear & Diagonal tension \\
\hline Ungrouted & 15.3 & 0.21 & 0.51 \\
Grouted & 25.4 & 0.60 & 1.00 \\
\hline
\end{tabular}

\subsection{Wall configuration and construction details}

Three full-scale PG masonry shear walls; namely, single cell/bond beam reinforcing (SR), double cell/bond beam reinforcing (DR) and double cell/bond beam reinforcing with bed-joint reinforcement (DR-JR) were tested under constant axial compressive stress and increasing lateral top cyclic displacement. The vertical reinforcement in SR and DR specimens consisted of $1 \mathrm{D} 19$ and $2 \mathrm{D13}$, respectively as shown in Figs. 4a and b. Wall DR-JR has the same vertical and horizontal steel as wall DR with the addition of ladder-type bed-joint reinforcement every other course as shown in Fig. 4c. All specimens had vertical reinforcement ratio of approximately $0.1 \%$ of net area. However, horizontal reinforcement ratio of SR, DR and DR-JR walls were equal to $0.08 \%$ and $0.1 \%$, respectively. This difference in horizontal steel ratio is mainly due to presence of bed-joint reinforcement in wall DR-JR.

Net area of walls was calculated based on the hollow section by considering the face shell, web and area of grouted cells. Wall dimensions and reinforcement configuration details are presented in Table 2. It is worth mentioning that these walls are considered the largest PG masonry shear walls ever tested and reported in the literature. Fig. 5 shows details of wall construction such as the horizontal and vertical hooks, bed-joint reinforcement and connection between the wall and the loading beam. All details were duplicated for the three specimens. 
Table 2 Dimensions and reinforcement configurations for test specimens

\begin{tabular}{|c|c|c|c|c|c|c|c|c|}
\hline \multirow[b]{2}{*}{ Wall ID } & \multirow{2}{*}{$\begin{array}{l}\text { Height } \\
(\mathrm{mm})\end{array}$} & \multirow{2}{*}{$\begin{array}{l}\text { Length } \\
(\mathrm{mm})\end{array}$} & \multirow{2}{*}{$\begin{array}{l}\text { Width } \\
(\mathrm{mm})\end{array}$} & \multirow[b]{2}{*}{$H / L$} & \multicolumn{2}{|c|}{ Reinforcement } & \multirow{2}{*}{$\begin{array}{l}\text { Reinforcement } \\
\text { spacing } \\
(\mathrm{mm})\end{array}$} & \multirow{2}{*}{$\begin{array}{c}\text { Axial } \\
\text { stress } \\
\mathrm{MPa}\end{array}$} \\
\hline & & & & & Vertical & Horizontal & & \\
\hline $\begin{array}{l}\text { SR } \\
\text { DR } \\
\text { DR-JR }\end{array}$ & 3,860 & 3,860 & 200 & 1 & $\begin{array}{c}\mathrm{D} 19 \\
2 \mathrm{D} 13 \\
2 \mathrm{D} 13\end{array}$ & $\begin{array}{c}\mathrm{D} 19 \\
2 \mathrm{D} 13 \\
2 \mathrm{D} 13\end{array}$ & 1,830 & 0.14 \\
\hline
\end{tabular}

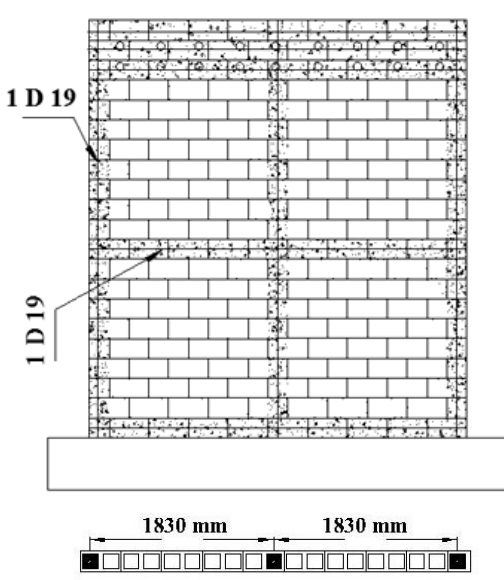

(a) Single reinforcement (SR)

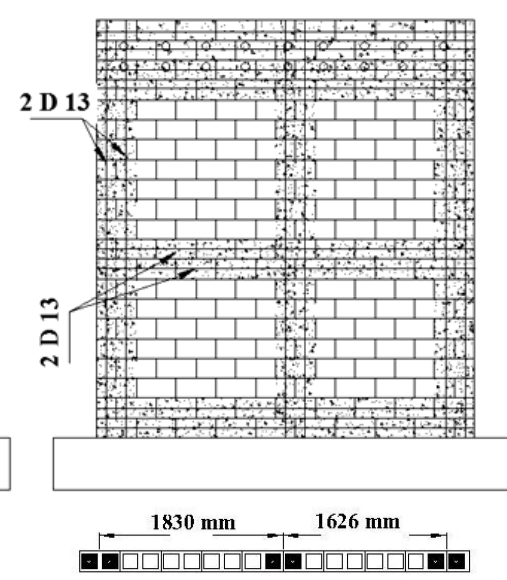

(b) Double reinforcement (DR)

Fig. 4 Reinforcement configuration

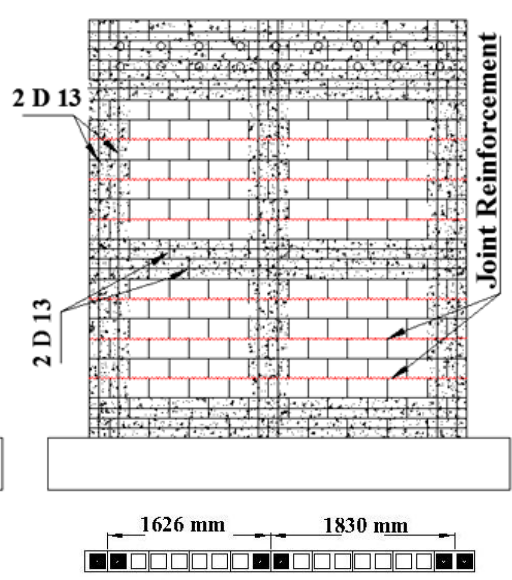

(c) DR with bed-joint reinforcement (DR-JR)

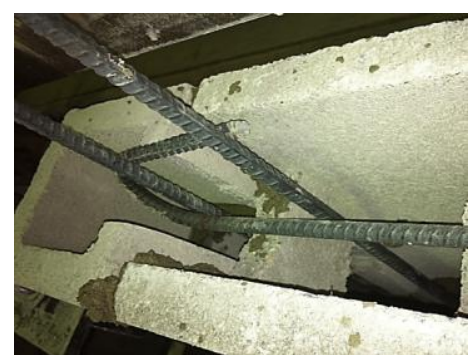

(a) Horizontal bar with 180 degree hook around end vertical bar

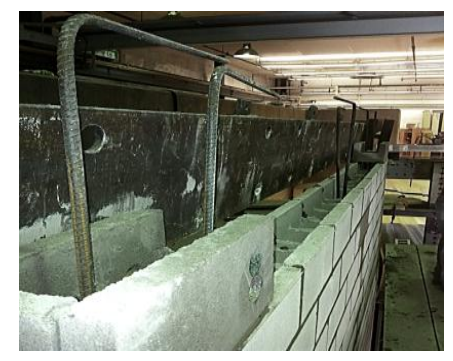

(b) Vertical bar with 90 degree hook

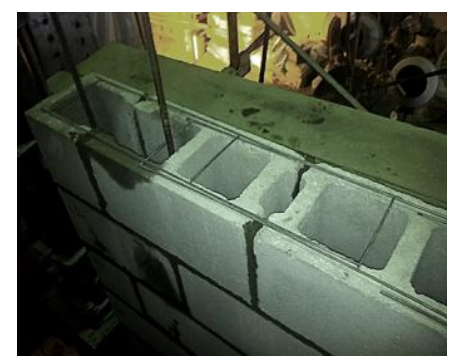

(c) Ladder-type bed-joint reinforcement

Fig. 5 Construction details

\subsection{Test setup and instrumentation}

A horizontal actuator at the top and two vertical actuators on the two sides transferred the load and displacement through the two stiff channel beams (called loading beam herein) which were post-tensioned to the wall, see Fig. 6 . The boundary conditions of the three walls were considered as a cantilever with the inflection point at the top of the walls with an aspect ratio $(H / L)$ of 1.0 . Two vertical actuators were 
programmed to impose the axial compressive stress without any resistance against the wall rotation (i.e. when the horizontal actuator is pushing the wall, right side actuator arm becomes shorter and left side actuator becomes longer without altering the applied force). To prevent the wall from moving out-of-plane, the test specimen was restrained with hinged out-of plane supports at the top. Also, two additional courses were built above the target height of the wall to provide enough development length of the vertical rebars, and also properly transferring the horizontal load to the wall. Although it is necessary to provide two extra courses at the top due to experiment constrain, this configuration increases only the local in-plane stiffness of the wall at the top. However, it does not affect the global behavior of the walls due to small amount of overturning moment at the top of walls. Pre-stress loading beam was also used to simulate the same effect of connection of diaphragm to the wall in the wall plane which is throughout the cross section of the wall in the practice. Walls were tested under $0.14 \mathrm{MPa}$ axial compressive stress (using net cross sectional area as defined before) to simulate gravity loads of one story building.

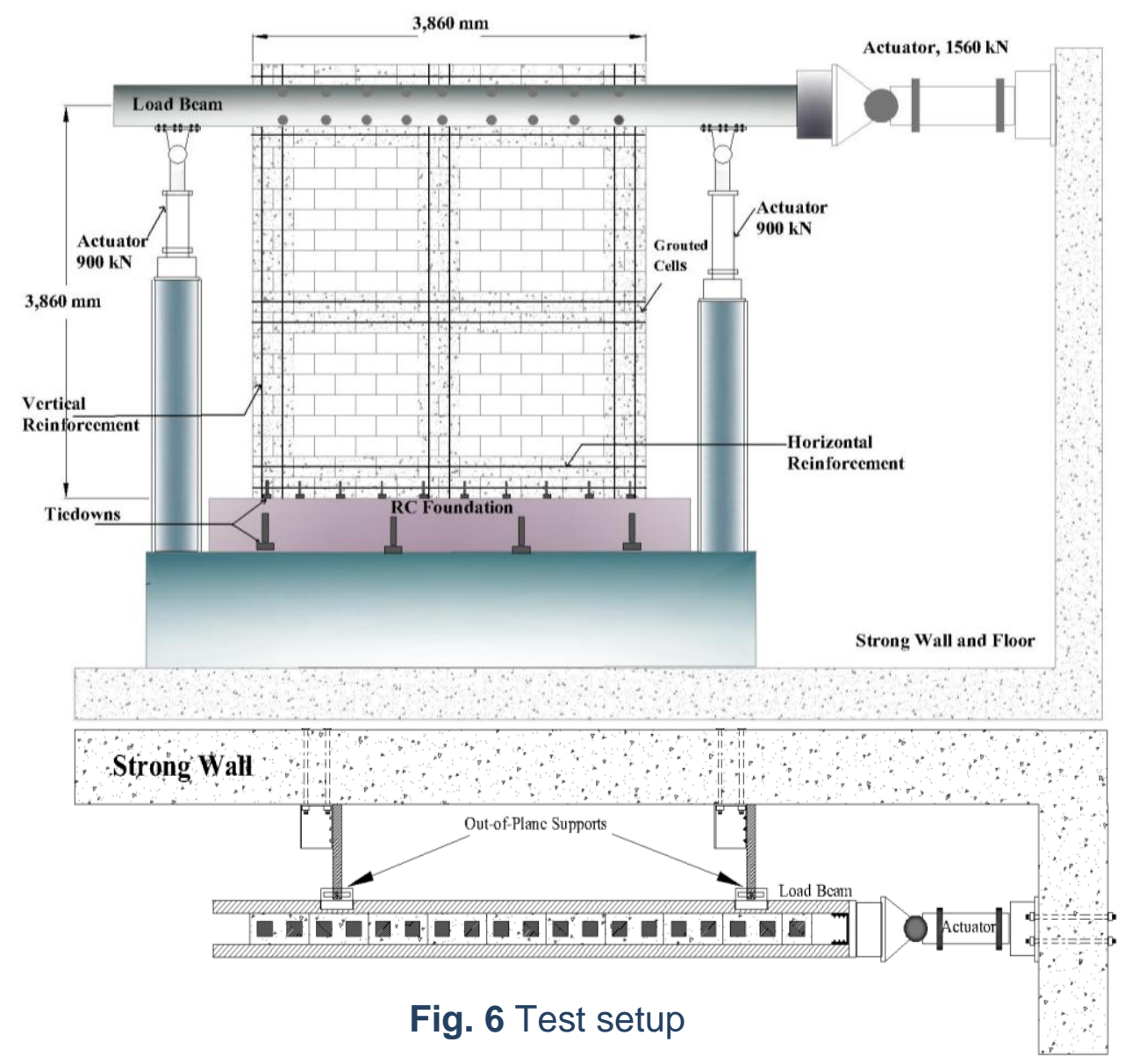


Fig. 7 depicts instrumentation used to measure flexural and shear deformation of the test specimen. Linear Variable Differential Transformers (LVDT, Schaevitz DC-SE 4000) and strain-gage based displacement transducers (TML, CDP-25) were used to measure wall deformations and displacements using OPTIM data acquisition system. Three load cells were used to measure the applied horizontal and vertical loads.

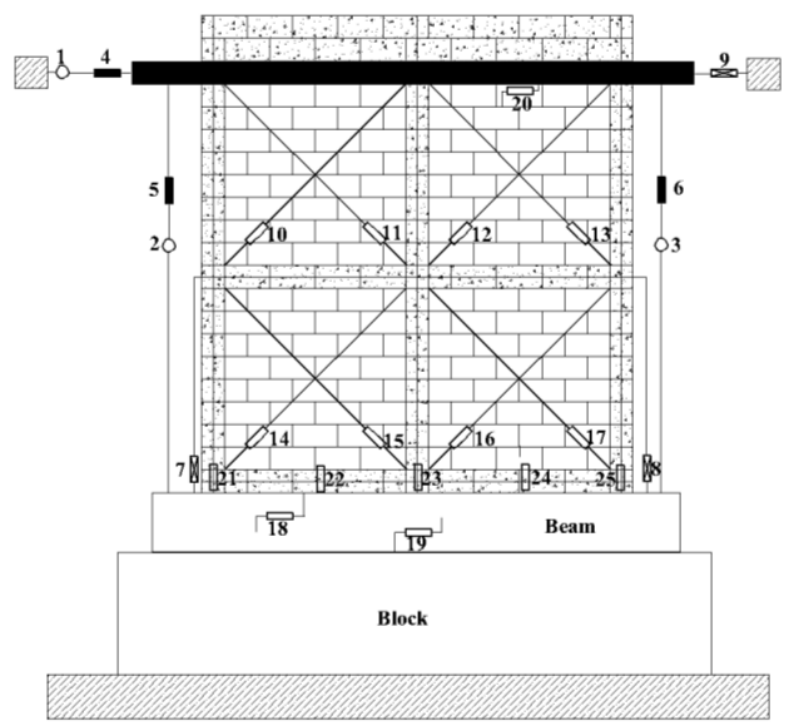

\begin{tabular}{|l|l|l|}
\hline $\begin{array}{c}\text { Sensor } \\
\text { Number }\end{array}$ & Label & \multicolumn{1}{|c|}{ Discription } \\
\hline 1,2 and 3 & - & Actuators load cell \\
\hline 4,5 and 6 & - & Actuators LVDTs \\
\hline 7,8 and 9 & - & $\begin{array}{l}\text { LVDT - measuraing lateral and vertical } \\
\text { displacement }\end{array}$ \\
\hline $10-17$ & $\square$ & $\begin{array}{l}\text { TML, CDP-25 sensor (strain gauge) - measuring } \\
\text { deformation of wall }\end{array}$ \\
\hline 18,19 and 20 & $\square$ & $\begin{array}{l}\text { TML, CDP-25 sensor (strain gauge) - measuraing } \\
\text { sliding }\end{array}$ \\
\hline $21-25$ & $\square$ & $\begin{array}{l}\text { TML, CDP-25 sensor (strain gauge) - measuraing } \\
\text { displacement at the base of wall }\end{array}$ \\
\hline
\end{tabular}

Fig. 7 Instrumentation

\subsection{Test procedure}

Test was conducted under quasi-static displacement control and loading rate of $0.7 \mathrm{~mm} / \mathrm{min}$. Reversed displacement cycles were applied at the top of walls to reach to defined drift index by ATC 2000 (FEMA 356 [24]). Also two cycles at each drift level were imposed. Input displacement history and different limit states [Immediate Occupancy (IO), Life Safety (LS), and Collapse Prevention (CP)], are showed in Fig. 8.

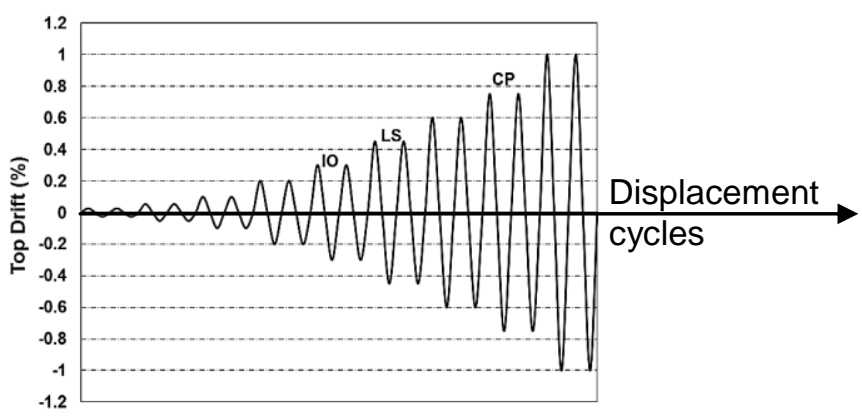

Fig. 8 Displacement time history and Input drift index 


\section{Experimental results and discussion}

\subsection{Crack patterns and failure mode}

Figs. 9 and 10 show the final crack patterns and crack propagation of walls at different limit states (IO, LS and CP), respectively. It is to be noted that two cycles of each drift have been applied, therefore, all crack patterns referenced are those related to the second cycle. All specimens displayed the same elastic behavior up to $0.05 \% \mathrm{drift}$ and a load of about $113 \mathrm{kN}$. No visible cracks occurred at this drift level. A few flexural bed and head joint cracks appeared at $0.2 \%$ drift, in all specimens irregularly across the walls. Additionally, diagonal Zigzag de-bonding joint cracks developed in the hollow portion of the walls and diagonal cracks were observed in the bottom and top part of masonry panels simultaneously at $0.3 \%$ drift for all specimens. This type of crack is similar to what was observed for the hollow diagonal tension specimen (Fig. 3a). It can be described that principal tensile stresses arise perpendicular to the compressed diagonal units at this drift level. Diagonal cracks propagate in a step pattern due to the mortar bed and head joints being the weakest elements of the walls. As testing continued, the crack propagation and crack growth of walls start to become different. For instance more diagonal cracks in wall SR and horizontal cracks in wall DR developed at the bottom panels because of higher shear and flexural stresses, respectively. Therefore, as shown in Fig. 9 the general crack patterns of walls are not similar, for the higher drifts the crack pattern of walls are discussed as follows:

SR wall- In wall SR only a few new cracks appeared at toes (at $0.45 \%$ drift) and the previous cracks width enlarged. By reaching to the lateral drift of $0.6 \%$, vertical splitting cracks and toe crushing was observed. The size of step cracks enlarged and developed through the full diagonal length by passing the bond beam and grouted cells. Similarly, shear failure mechanism abruptly occurs in wall SR due to low stiffness and weak strength of these elements. However, load dropped gradually in wall DR as beams and piers were strong enough to carry the load before the failure (Fig. 9a). 
DR wall- A few bed-joint cracks close to the middle bound beam occurred in wall DR at $0.45 \%$ drift. By continuing the test at the drift level of $0.6 \%$ and $0.75 \%$, bunch of head and bed-joint cracks were formed in the hollow panels and cracks extended into the grouted cells. Splitting cracks and toe crushing were not observed up to this point and most of the cracks occurred at the inferior hollow panels. The last cycle was applied at the drift level of $1 \%$, where 45 degree cracks were observed on the toe. The test was stopped at this point for safety reason (Fig. 9b).

DR-JR wall- Crack propagation at the early cycles in wall DR-JR was the same as wall DR. However, the amount of cracks appearing on the hollow panels of the wall was significantly more than other walls. Bed-joint reinforcement resulted in more crack distribution while the crack width was thinner (Fig. 9c).

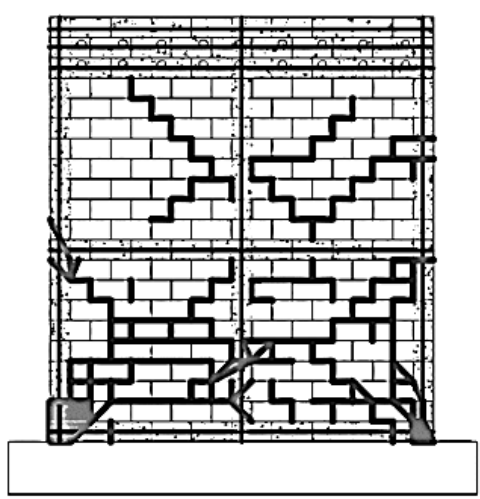

(a) SR wall

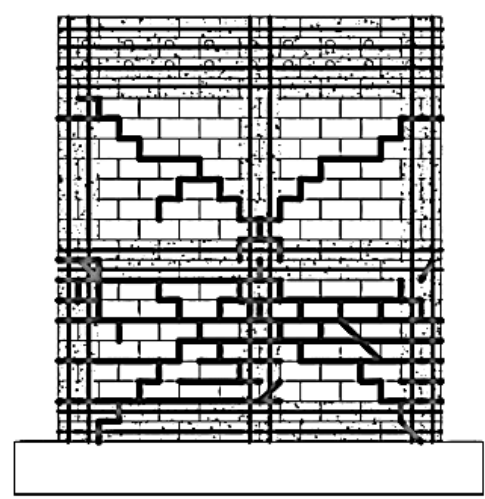

(b) DR wall

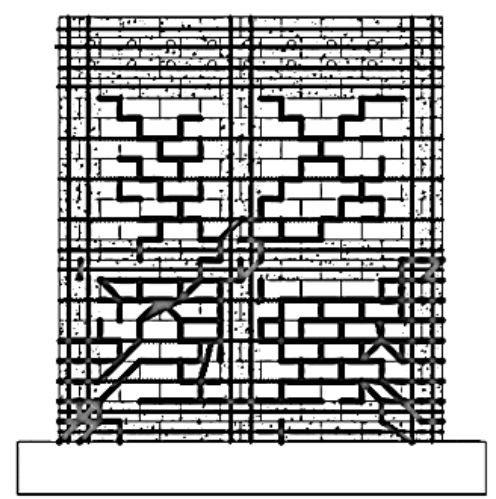

(c) DR-JR wall

Fig. 9 Crack patterns

Bed-joint reinforcement only controlled the crack size of wall panels without any strength enhancement in the flexural failure mode. In the walls without bed-joint reinforcement, after diagonal cracks formed, by increasing the lateral displacement the existed cracks opened extensively and the rest of hollow panels remain sound. Distributed bed-joint reinforcement across the wall height enabled the distribution of stress in the hollow panels. 


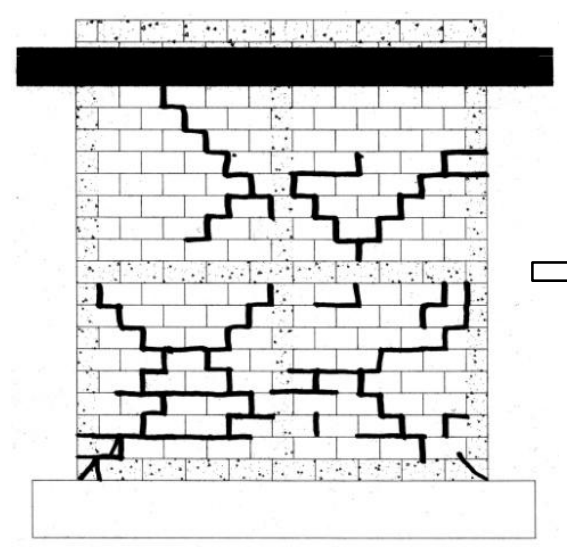

(I) 10
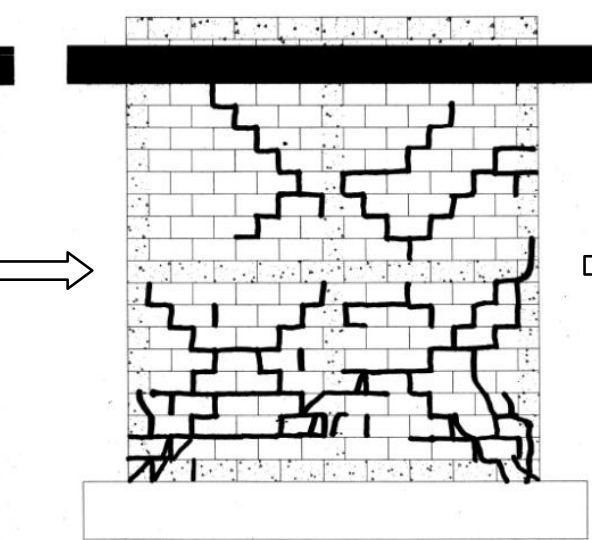

(II) LS

(a) SR wall

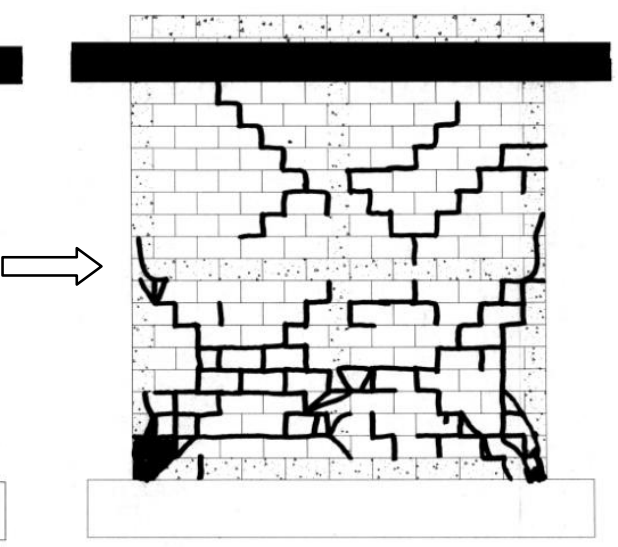

(III) $\mathrm{CP}$

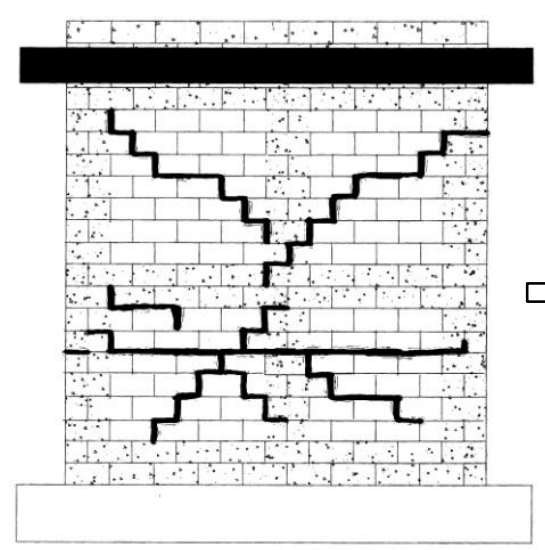

(I) 10

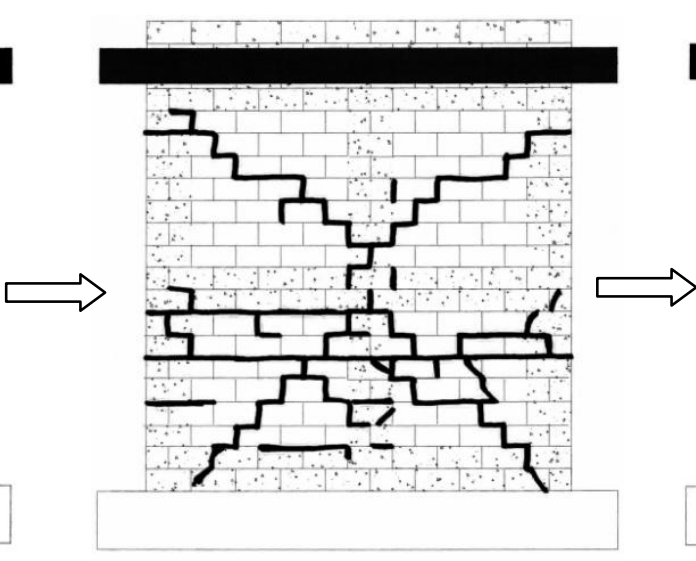

(II) LS

(b) DR wall

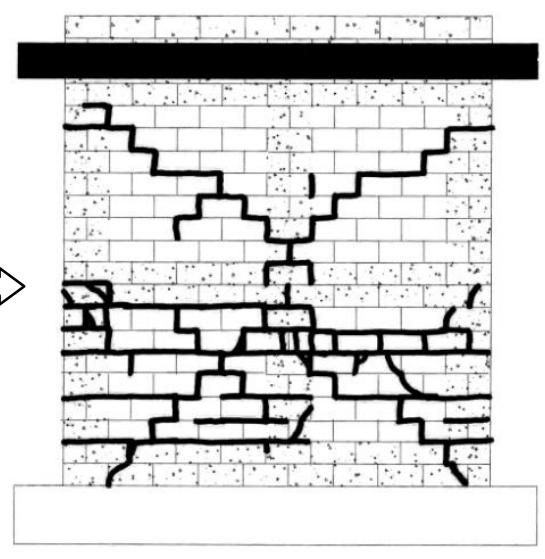

(III) $\mathrm{CP}$

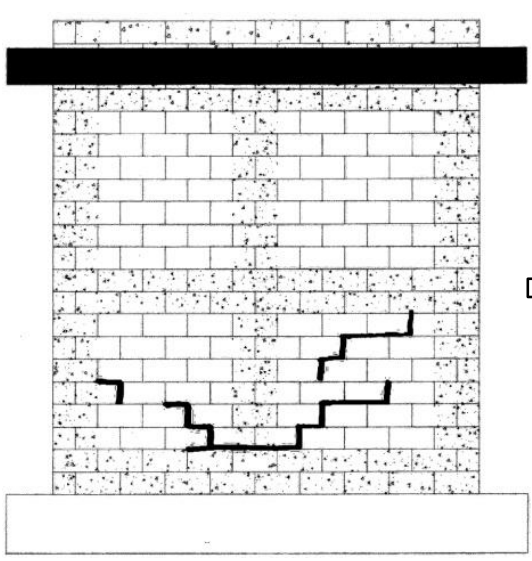

(I) 10

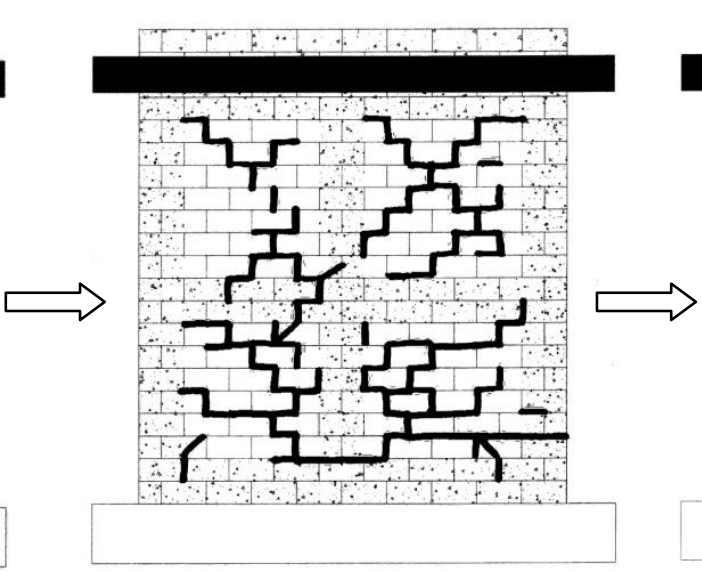

(II) LS

(c) DR-JR wall

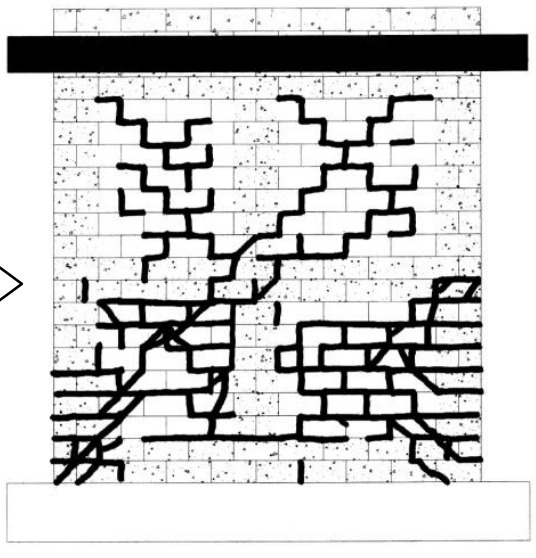

(III) $\mathrm{CP}$

Fig. 10 Crack propagation 
Consequently, the initial cracks under increasing lateral displacement did not open significantly and new set of cracks spread at the wall height. Therefore as Fig. 9 shows, the number of cracks in the hollow panels of wall DR-JR is clearly more than other walls. Wall SR exhibited a shear mode of deformation as evident from the drastic post-peak degradation of the hysteresis loops (Fig. 11a) whereas DR and DR-JR walls exhibited a flexural mode of deformation as evident from more stable hysteresis loops post the peak and higher displacement (Figs. 11b and c).

\subsection{Load-displacement relationships}

Fig. 11 shows the lateral force-lateral displacement at the top of SR, DR and DRJR walls. Sliding displacements at the bottom of specimens were subtracted from the curves. The maximum drift level of the SR wall was $0.45 \%$ meeting LS limit state. SR wall exhibited a shear mode failure as evident from the drastic shear strength degradation of the hysteresis loops while DR and DR-JR walls had a flexural failure mode. Basically, the rapid strength degradation of the SR wall at peak load, not satisfying LS limit state, is the major drawback that was overcame by using double reinforcing cells/bond beams in DR and DR-JR walls.

Wall SR displayed a rocking behavior causing toe crushing whereas for wall DR, more diagonal cracks and sliding between inferior courses were developed resulting in a more ductile behavior (Fig. 12a). As can be seen in Fig. 12b the behavior of DR-JR and DR walls is similar and bed-joint reinforcement did not contribute to enhancement of lateral in-plane response of the wall. Bed-joint reinforcement prevented sudden drop in load as cracks developed. This is evident from smoother load-displacement curves. Moreover, bed-joint reinforcement at the large deformation cycles works properly and the energy dissipation of DR-JR is more than wall DR, this subject will be further discussed in the energy dissipation and damping factor section. 


\subsection{Wall stiffness}

The stiffness of SR and DR and DR-JR walls at $1 / 3$ the ultimate load is 72.5 and $108 \mathrm{MN} / \mathrm{m}$, respectively. This $60 \%$ increase in stiffness of DR over SR wall is mainly attributed to the increase in section area and moment of inertia due to increase in average wall cross sectional area and inertia with the additional grouted cells and bond beams. Effective rigidity based on ACI 318-11 [25] code was also calculated and the stiffness of single and double grouted walls were 209 and $227 \mathrm{MN} / \mathrm{m}$, respectively. Results showed that the code overestimates the stiffness of walls by $2 \sim 3$ times. This was expected since the equation is not fully applicable for PG masonry walls.

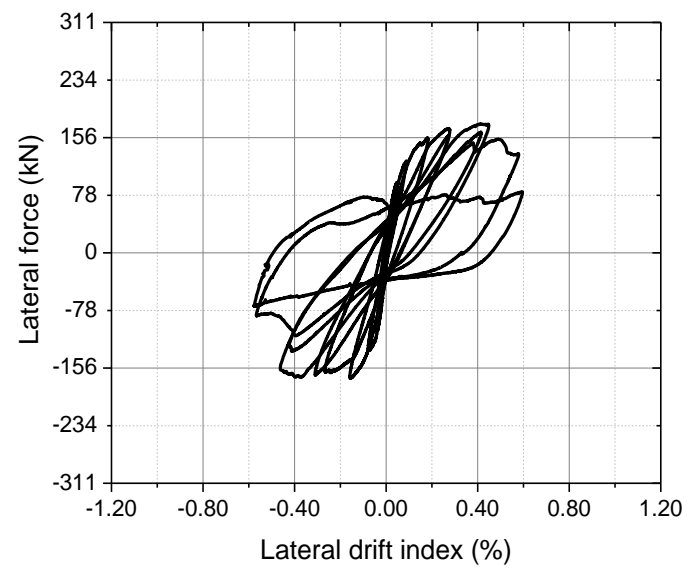

(a) SR wall

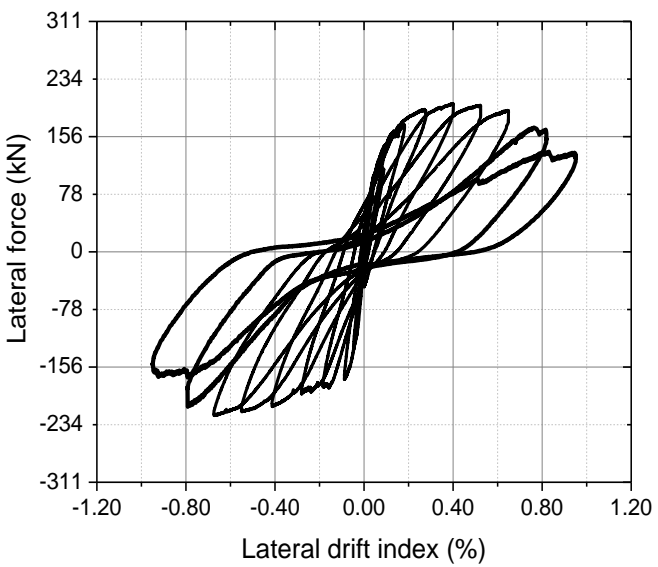

(b) DR wall

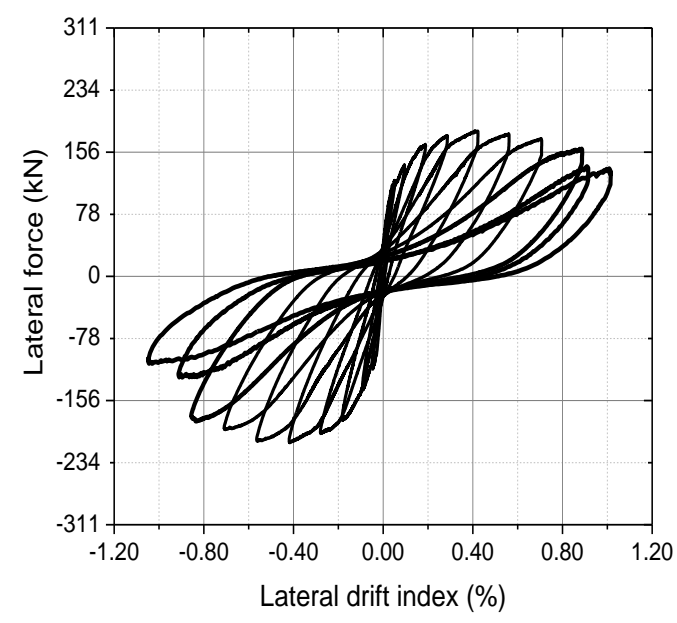

(c) DR-JR wall

Fig. 11 Lateral force displacement hysteresis loops 
Distributing the steel ratio of single cell to double cells increases the primary stiffness and delays the crack propagation in the wall, as a result of couple reinforcement. In the elastic part, wall DR shows better performance in comparison to wall SR. By increasing the displacement the reinforced cells and courses of walls deformed through the frame action and hollow panels act as an infill. The panel stiffness degradation caused by cracks in DR wall is less than SR wall and the tensile stresses due to shear force can be adequately transferred across the diagonal cracks. Due to higher strength and deformability of grouted cells in wall DR, the load redistributed into the hollow panels and new set of cracks occurred across the wall. However, due to weak interaction between hollow panels and the frame most part of existed load in SR wall is carrying by the toe. This dropped the stiffness of the wall significantly because of severe cracks at the toe.

In order to study the effect of single and double grouted cell configurations on the stiffness of the wall, a simple linear model was also developed. Although the specific behavior of masonry components is not considered in the linear analysis, it can well predict the behavior of masonry [26]. Therefore, linear elastic analysis of equivalent infiled-frame with diagonal hollow masonry compression struts was performed assuming pin connections for wall SR (Fig. 12a) and rigid connection for wall DR (Fig. 12b).

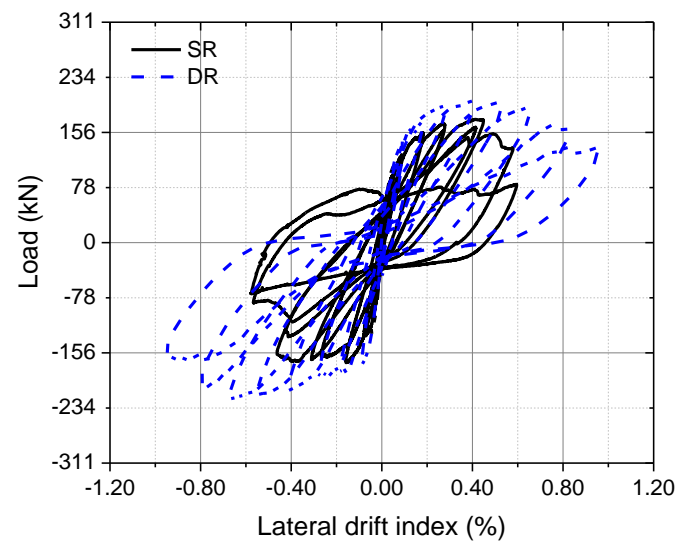

(a) Effect of single versus double reinforcing cells/bond beams

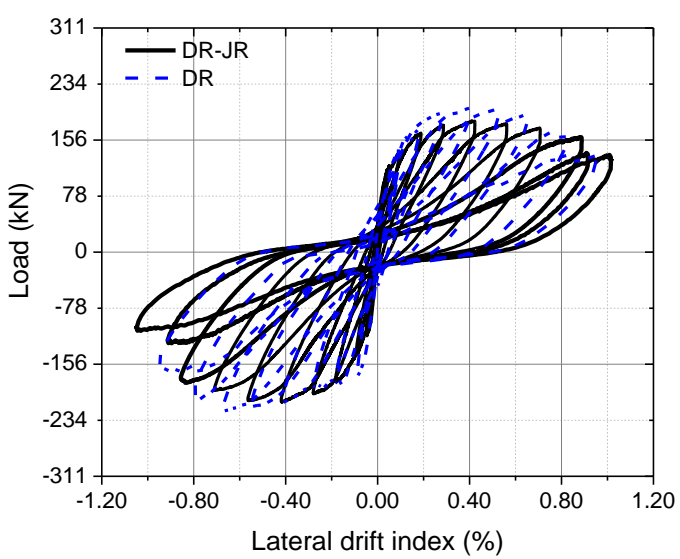

(b) Effect of bed-joint reinforcement

Fig. 12 Effect of reinforcement details on load-displacement curves 
The location of columns and beams was selected based on center line of grouted cells. This Linear elastic analysis based on uncracked section properties revealed a $57 \%$ increase in stiffness that is in close agreement with the experimental finding. The modules of elasticity of hollow prism (tested in this study $21 \mathrm{GPa}$ ) were used as an elasticity of struts dimensions of struts, beams and columns are shown in Fig. 13. The width of struts was selected based on the New Zealand code [27] and the analysis was performed in the SAP2000 [28]. It appears that the ability of the grouted vertical cells/horizontal bond beams connection to carry moment resulted in reduction of flexural deformation-lateral drift and consequently an increase in the wall stiffness.

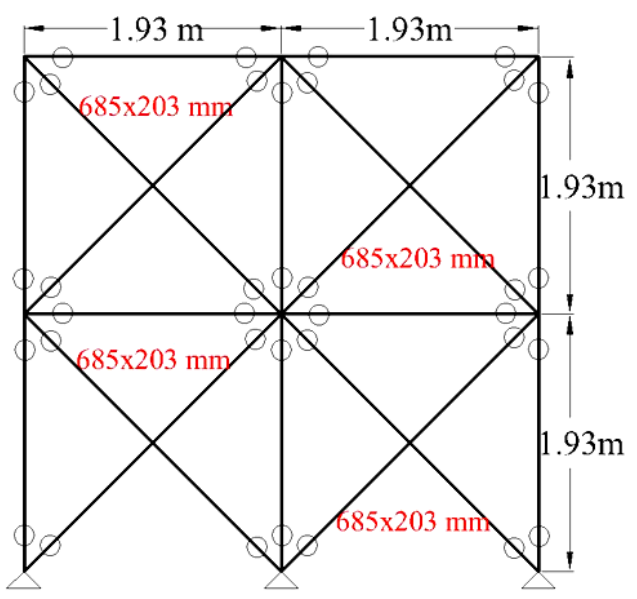

Columns \& Beams are: $203 \times 203 \mathrm{~mm}$ SR Wall

(a) Frame with pin connection

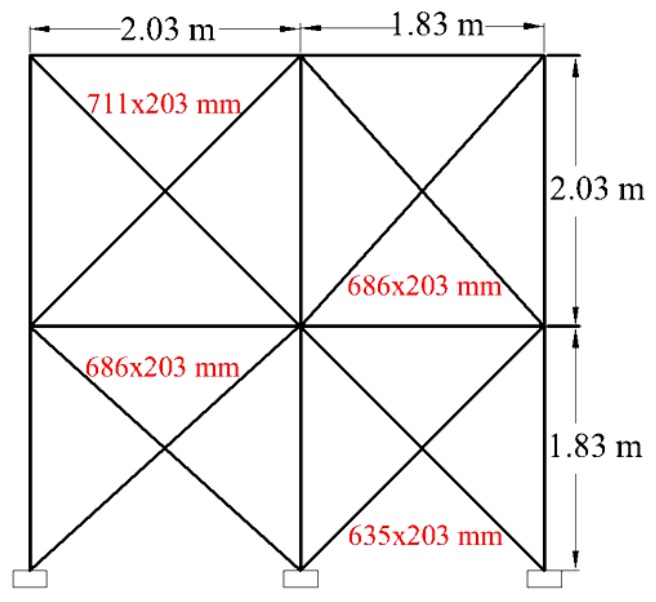

Columns \& Beams are: $406 \times 203 \mathrm{~mm}$ DR Wall

(b) Frame with rigid connection

Fig. 13 Stiffness analysis of wall as infilled-frame with diagonal struts

\subsection{Wall shear strength}

The shear capacity of SR, DR and DR-JR walls were 168, 221 and $208 \mathrm{kN}$, respectively. The shear strength increased by 34 for wall DR compared to the SR wall. As previously mentioned SR wall exhibited abrupt strength degradation after peak and onset of severe cracks at the toe of walls. The tensile stress caused by shear force cannot be transferred appropriately across the diagonal cracks of SR wall and cracks were extensively opened. Double horizontal reinforcing cells delayed the propagation of shear cracks and enabled the distribution of stresses crosswise the entire wall after 
onsets of cracks. Therefore, wall DR showed a gradual strength degradation beyond the ultimate shear strength, this dramatic increase in the wall capacity may be attributed to the ability of the connection between the grouted reinforced cells and the reinforced bond beam, in case of DR wall, to carry moment (Fig. 14). However, as showed in the idealized model the connections in SR wall acting as a pin which cannot carry moment.
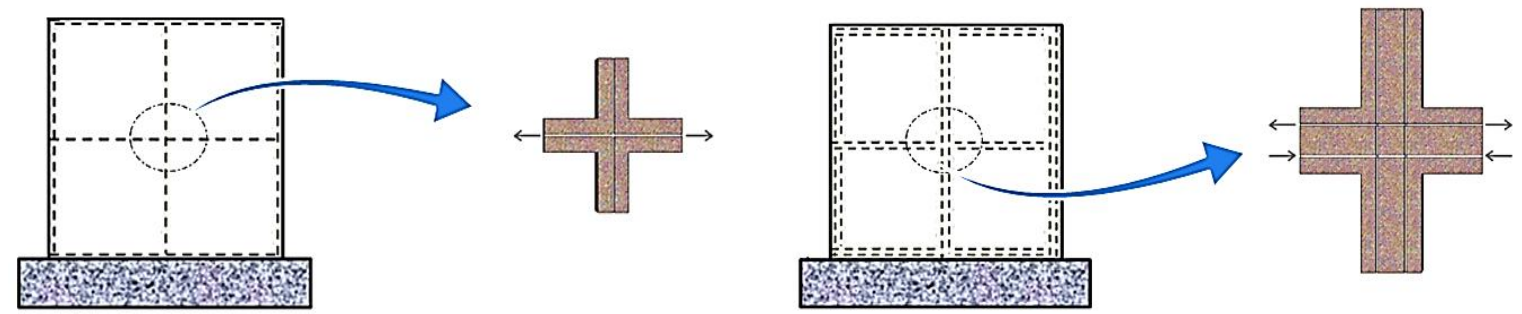

Fig. 14 Connection of vertical grouted cells and horizontal bond beams

These connections carry moment and system is more ductile, by increasing the number of plastic hinges in the structure due to growing stresses. This explanation assumes an infiled-frame behavior at the ultimate limit state. In the wall SR before forming cracks at the edges step cracks in the center of hollow panels initialized by the shear action. Due to the high tensile stress concentration these cracks propagated diagonally up to the wall failure. The size of cracks at the middle of hollow panels grows by increasing the lateral displacement. By increasing the lateral load cracks initiate at the edge of the hollow panels which are close to the grouted cells. However, these cracks propagate in the grouted cells due to the weak connection (using single bar in wall SR) between the lower beam and piers. Therefore, coupling effect cannot be in action and a big portion of load is transferred directly through the struts towards to the wall toes by showing toe crushing at the edges.

Conversely, cracks in the hollow panels of wall DR are initiates at the center and also the edges of panel simultaneously. The same mechanism could occur in the DR wall, however because of using two side-by-side rebars coupling effect becomes effective and beams carry some parts of the load in wall DR. Consequently, deflection of beams becomes significantly larger than wall SR and as a result, lots of horizontal cracks formed at the top and bottom of beams. Finally, the strength of wall DR 
increases, the difference in the wall capacity derives from coupling effect between piers and beams.

Using bed-joint reinforcement increases the amount of shear reinforcement in the DR-JR wall slightly. However, it does not affect the shear strength. Apparently, the bedjoint reinforcement was not engaged effectively since the wall exhibited a flexural mode of deformation. Although, using bed-joint reinforcement did not enhance the wall seismic performance the size and number of cracks observed were visibly less than those for specimens without bed-joint reinforcement.

\subsection{Wall curvature and displacement ductility}

Wall curvature is calculated at the maximum drift by considering the readings of TMLs 7, 8 at the mid high and 21, 25 at the bottom of walls (sensors 7 and 8 were taken off after $0.6 \%$ drift due to large deformation exceeding sensors' capacity). Curvatures along wall height are plotted in Fig. 15 for the three wallls. Since the walls were tested as a cantilever beam, the curvature at the top of walls is expected to be zero. As shown in the Fig. 15, inelastic deformation started at mid-hight of the wall and extended to the base. This indicates that length of plastic hinge is roughly equal to 0.5 times the wall height. Wall DR with double reinforcement exhibiting flexurally-dominating behavior, showed curvature that is 40 percent higher than wall SR with single reinforcement (exabited shear-dominating behavior).

As can be seen from Fig. 15, the shape of curvature of wall DR-JR is the same as for the DR wall. However, curvature at the top part of wall DR-JR is higher than wall $\mathrm{DR}$, this can be attributed to uniformity of specimen at the top because of bed-joint reinforcement confinement. Instead of wide step cracks on the hollow part, courses between bed-joint reinforcements rotate uniformly and this led to bigger curvature. This is not true for the bottom part of wall since severe cracks took place on this area which makes the behavior of wall totally different than top part. 


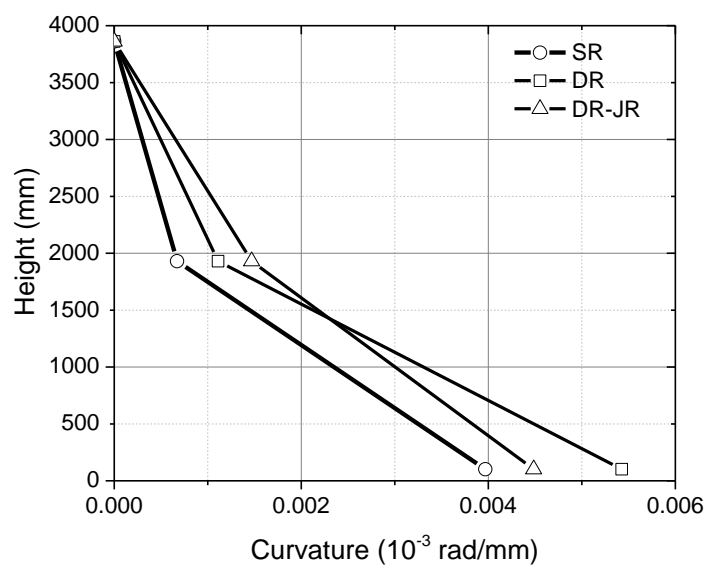

Fig. 15 Curvature variation along wall height

Displacement ductility is calculated as $d_{u} / d_{y}$, see Fig. 16 [7]. Envelope curves of walls are plotted in Fig. 17, values of yielding $d_{y}$ and ultimate $d_{u}$ displacements are also presented in Table 3 . Results show that $d_{y}$ was the same for all the specimens and that the double reinforcement detail resulted in a significant increase (47\%) in $d_{u}$ value and, consequently, the displacement ductility. DR wall displayed much higher deformation capacity compared to SR wall (Fig. 17a). Moreover, bed-joint reinforcement did not enhance the displacement ductility of the DR wall (see Fig. 17b).

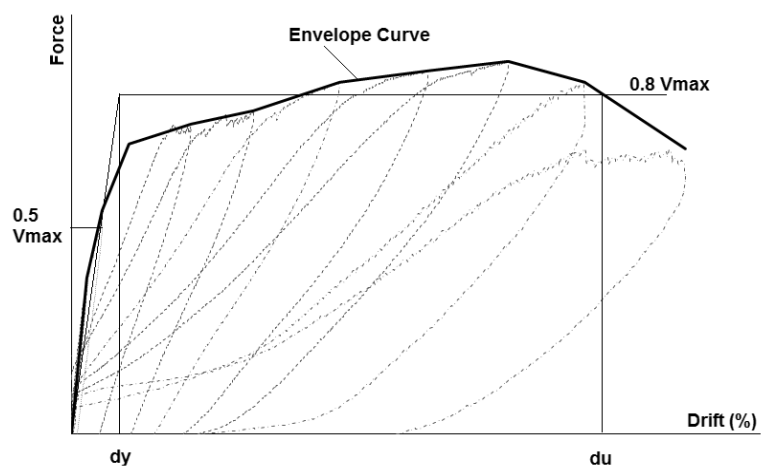

Fig. 16 Definition of displacement ductility

As mentioned, displacement ductility of DR wall increased by factor of 1.5 in comparison to wall SR (see Table 3). Similar observation have been made also in previous studies [21]. 
For studying the effect of diagonal struts on the response of walls, diagonal strain of hollow panels vs. the lateral load of each wall are plotted in Figs. 18 and 19. These figures show the absolute maximum of diagonal tension and compression strains at two inferior hollow panels of walls (see Fig. 7 for designated TML's). Wall SR reached the highest strain value at $0.6 \%$ drift $(168 \mathrm{kN})$ compared to $1 \%$ drift $(221 \mathrm{kN})$ for the DR wall. At a specific load, strain at the diagonal hollow panel of wall DR measured less than the SR wall (Fig. 18a). In addition, maximum strain discrepancy between wall SR and DR walls was more apparent in compression (with toe crushing) than in tension (with more distributed cracks) as can be seen in Fig. 18b. In the compression zone, diagonal strain of wall $S R$ is significantly less than wall $D R$ as the most of deformation dissipated by crushing the wall toes. However, in the wall DR diagonal struts carry almost three times of wall SR diagonal strain without showing any sign of crushing at the toes. The same results were also obtained in wall DR-JR compared with wall SR; however in the low drifts the strain value of diagonal panels are higher compare to the DR wall. This is due to redistribution of loads in the panels in the presence of bed-joint reinforcements. As shown in Fig. 19a, the diagonal strain values of hollow panels in wall $\mathrm{SR}$ and DR-JR are adjacent up to $150 \mathrm{kN}$ which shows that most of diagonal cracks occur up to this point.

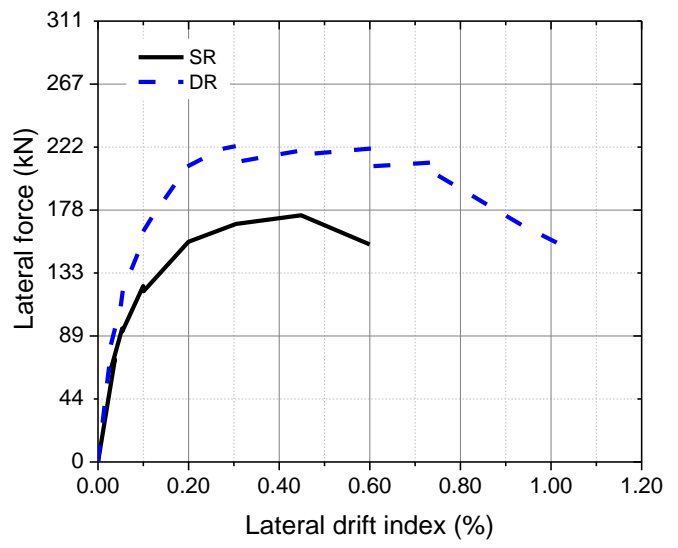

(a) SR vs. DR

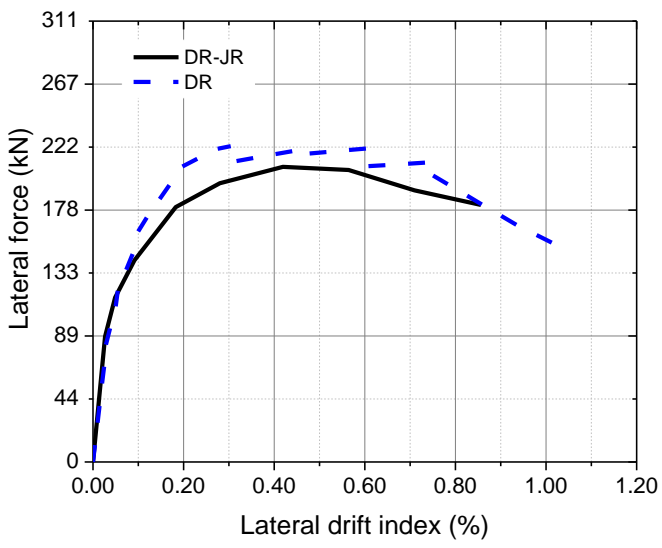

(b) DR vs. DR-JR

Fig. 17 Load-drift envelope diagrams 
Table 3 Walls displacement ductility

\begin{tabular}{lccc}
\hline \multirow{2}{*}{ Wall ID } & \multicolumn{3}{c}{ Displacement ductility } \\
\cline { 2 - 4 } & $\mathrm{d}_{\mathrm{y}} \%$ & $\mathrm{~d}_{\mathrm{u}} \%$ & $\mu_{\Delta}\left(\mathrm{d}_{\mathrm{u}} / \mathrm{d}_{\mathrm{y}}\right)$ \\
\hline SR & 0.08 & 0.60 & 7.5 \\
DR & 0.08 & 0.88 & 11 \\
DR-JR & 0.08 & 0.88 & 11 \\
\hline
\end{tabular}

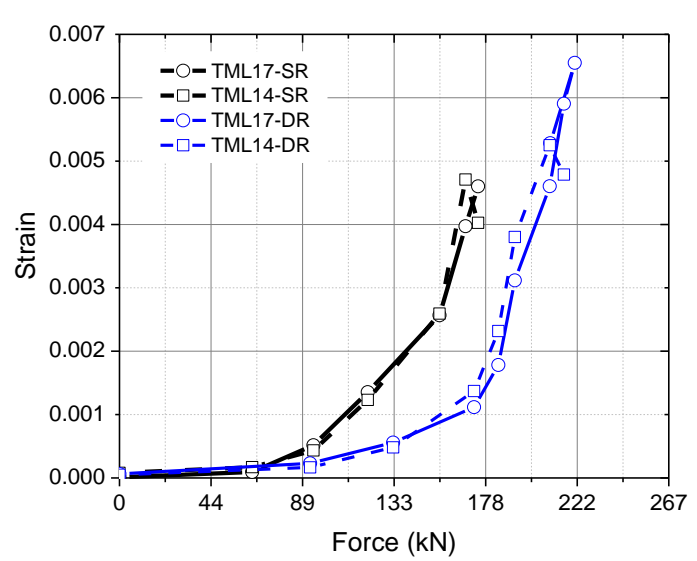

(a) SR and DR walls' diagonal tension strain-load curve

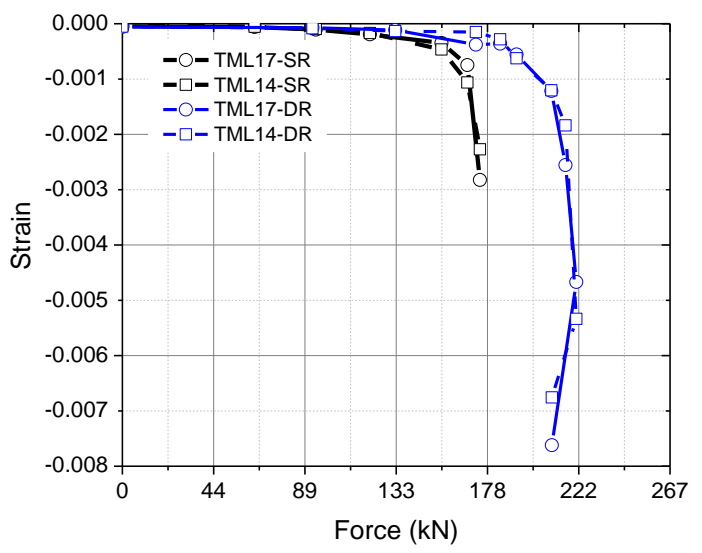

(b) SR and DR walls' diagonal compression strain-load curve

Fig. 18 Diagonal deformation

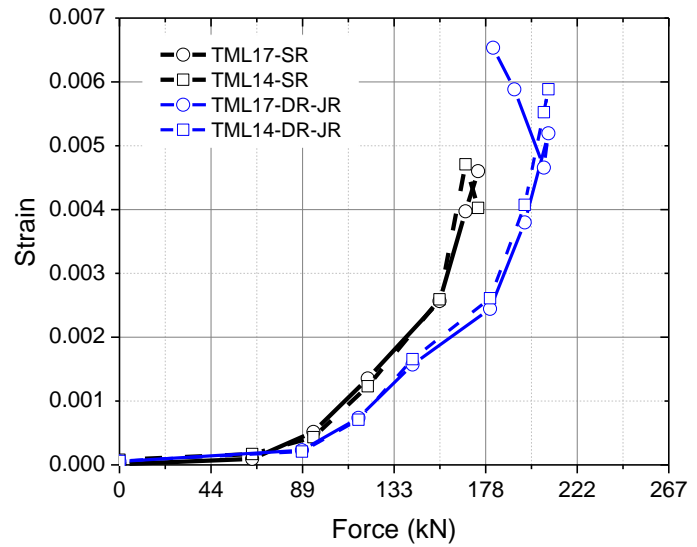

(a) SR and DR-JR walls' diagonal tension strain-load curve

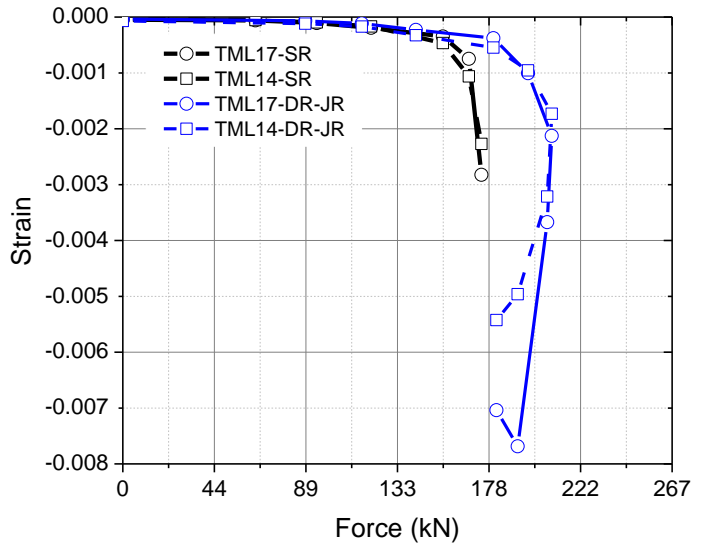

(b) SR and DR-JR walls' diagonal compression strain-load curve

Fig. 19 Diagonal deformation 


\subsection{Energy dissipation and damping factors}

Damping ratio of walls was calculated based on equation 1 for each cycle; $\mathrm{D}=\mathrm{W}_{\mathrm{d}} / 2 \pi\left(\mathrm{W}_{\mathrm{e}}^{+}+\mathrm{W}_{\mathrm{e}}^{-}\right)$

where $\mathrm{W}_{\mathrm{d}}$ is the area of cycles and $\mathrm{W}^{+}, \mathrm{W}_{\mathrm{e}}$ are the area of triangles generated from connecting the origin point to maximum and minimum load of each cycle, respectively. Results are shown in Fig. 20 a, from beginning to failure ( $80 \%$ of peak) of each wall. As can be seen, damping factors of the three walls are similar in the elastic range (a ratio of 0.1 ) up to a drift ratio of $0.45 \%$. At drift levels higher than $0.45 \%$ SR wall showed higher damping because of larger damage cracking and sliding at the bedjoints. As evident from Fig. 20, bed-joint reinforcement started dissipating energy after formation of wider cracks at a drift index greater than 0.5 percent.

Although this amount of energy dissipation is not considerable, using bed-joint reinforcement enhanced the damping factor for LS and CP limit states. In Fig. 20b and c, energy dissipation of the three walls in each cycle and cumulative energy dissipation are shown, respectively. As can be seen, energy absorption for all specimens was the same up to $0.5 \%$ drift ratio. However, energy dissipation of wall SR is higher than the other two walls at drift ratio of $0.6 \%$. Also, cumulative energy dissipation of the three walls (Fig. 20c) was the same up to $0.4 \%$ drift level. The SR wall showed larger energy dissipation at drift ratio of $0.4 \%$ to $0.6 \%$ compared to the other specimens. However, the total energy dissipation of these two walls is almost the same. 


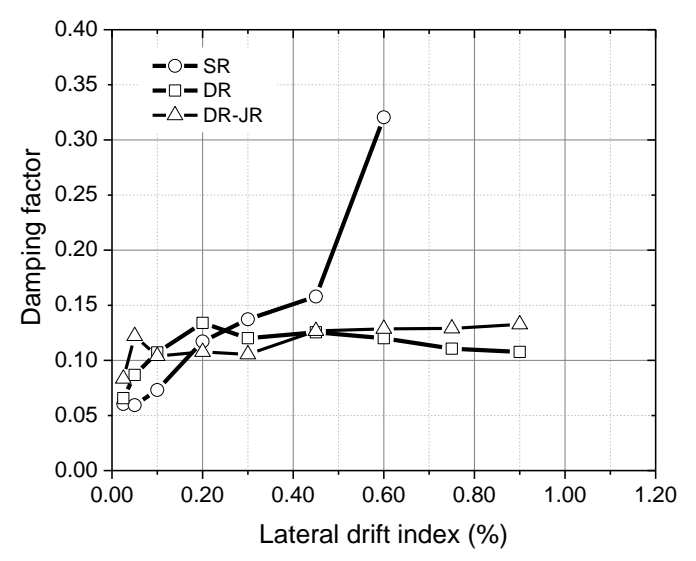

(a) Damping factor

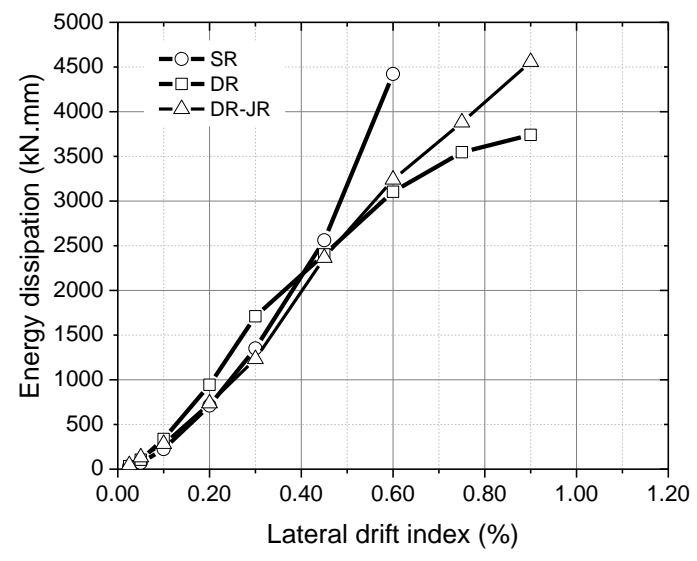

(b) Energy dissipation

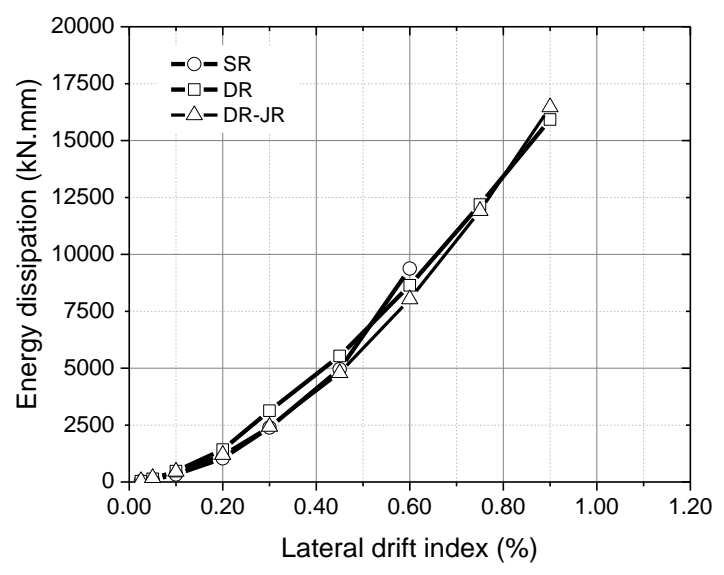

(c) Cumulative energy dissipation of walls

Fig. 20 Energy dissipation and damping factor

\section{Comparison with past studies}

In this section the effect of reinforcement configuration, bed-joint reinforcement, in addition to some of the test outputs such as crack pattern and failure mode are compared with those obtained in literature.

Reinforcement- The effect of vertical and horizontal reinforcement distribution on the in-plane response of PG masonry shear walls was investigated in [3] and [4]. It was concluded that the behavior and failure modes of PG masonry are strongly dependent on the distribution of reinforcement. Afterward, effects of different 
reinforcement quantities were tested in [7] Walls were nominally reinforced with shear reinforcement only in the top two courses. Results indicated that all specimens have bad performances in the cyclic load conditions by showing diagonal shear failure because of the lack of shear reinforcement. The same results were also reported in [21]. It was found that the seismic behavior of PG walls with $0.8 \mathrm{~m}$ horizontal spacing between vertical reinforcement is much better than those with $1.2 \mathrm{~m}$ [21]. Reported results about the role of reinforcement on the performance of $P G$ walls are in agreement with the current research findings which showed that using two grouted cells instead of one increases the shear and ductility capacity of walls.

Bed-joint reinforcement- Partially grouted walls with and without bed-joint reinforcement were tested in [5] under in-plane loads. Results showed that as the level of horizontal reinforcement increases the ultimate shear strength slightly increases while it has a negligible effect on the stiffness. This was attributed to the cracks that formed between grouted and ungrouted cells. These cracks tended to grow and disturb the anchorage region of horizontal reinforcement where these bars intersected the vertical cells. The same results of using bed-joint reinforcement were obtained in this study. Although the horizontal steel ratio in wall DR-JR was almost 20 percent higher than wall $\mathrm{DR}$, bed-joint reinforcement did not improve the strength and deformation capacity of $P G$ reinforced (double cells reinforcing) shear walls at the ultimate-limit state. However, bed-joint reinforcement resulted in controlling the crack width at the serviceability limitstate.

Crack pattern and failure mode- In the research [8], four PG shear walls designed under current masonry code were tested. Results demonstrated that walls designed by conventional method have a really poor seismic performance by showing the shear mode failure. Comparably, the same performance was observed in SR wall which was designed based on the current code. However, by grouting the neighbor cells in the wall DR, not only the strength of specimen increased but also the failure mode of the wall was changed from shear to flexural as expected. In particular, the crack pattern that was reported is the same as what found in the current research. Vanin and 
Foraboschi [29] showed that under these circumstances piers remain connected only by beams at the middle and top of the wall. As a result of propagating these diagonal cracks in the hollow portions strength and stiffness degrade and the wall shows a shear failure mode. Foraboschi [30] also showed that this increase in the shear strength of wall is mainly due to the level of coupling piers by beams. This phenomenon can significantly change the response of the masonry wall when existing spandrel and piers are stiff enough. This is the case in the doubly grouted wall while in wall SR the level of coupling is low due to very weak interaction between beams and cells and this connection cannot provide sufficient strength and deformation.

\section{Numerical modeling}

To explore the effect of grouting on the response of proposed wall configuration (doubly grouted) a numerical model was developed. A nonlinear masonry models developed in different studied (e.g. [31], [32], [33], and [34]) proved that the bricks, mortar and mortar/block interfaces have a big impact on the behavior of masonry structures and failure of masonry is mostly due to combination of mortar/block complex rupture and collapse of mortar and units. In this regard, a detailed micro model is needed to be developed for taking the effect of all the masonry components into account.

A simplified 3D micro model is employed here to build the model by considering units, grout and their interfaces. Masonry units and grout are modeled as a solid block and solid concrete, respectively. Additionally, mortar joints and blocks are combined into a homogeneous unit material by applying concrete damage plasticity (CDP) model. Interface elements were also employed to model discontinuity between units in the hollow panels using cohesive surface-based behavior.

Present model has been developed previously based on experimental results of grout, unit, mortar and also different hollow and grouted masonry assemblages which were constructed and tested before testing the actual walls. It is worth mentioning that the model was able to successfully capture the stress and strain curve, crack pattern 
and strain distribution of hollow and grouted assemblages [35]. Therefore, the same model has been employed in the current study for modeling tested walls and also extending it for investigating the effect of other parameters controlling the response of doubly grouted PG masonry shear walls. Details of the model have been published by authors previously (please refer to [35]), however for the sake of readability, a summary of model concepts and parameters are presented below.

\subsection{Constitutive models}

Concrete damage plasticity- The CDP model available in Abaqus was employed to simulate the nonlinear response of the masonry units and grout. CDP model assumes that the uniaxial compressive and tensile response of concrete is characterized by damaged plasticity. All the model parameters can be derived from the compression and tensile behavior of defined materials. For this purpose, stress-strain curves of hollow and grouted prisms tested in this study were used as inputs for the compressive behavior of hollow and grouted parts of the CDP model (Fig. 21a). Additionally, data collected in the horizontal direction of hollow and grouted diagonal tension specimens were used for the tensile behavior of the model as shown in Fig. $21 b$.
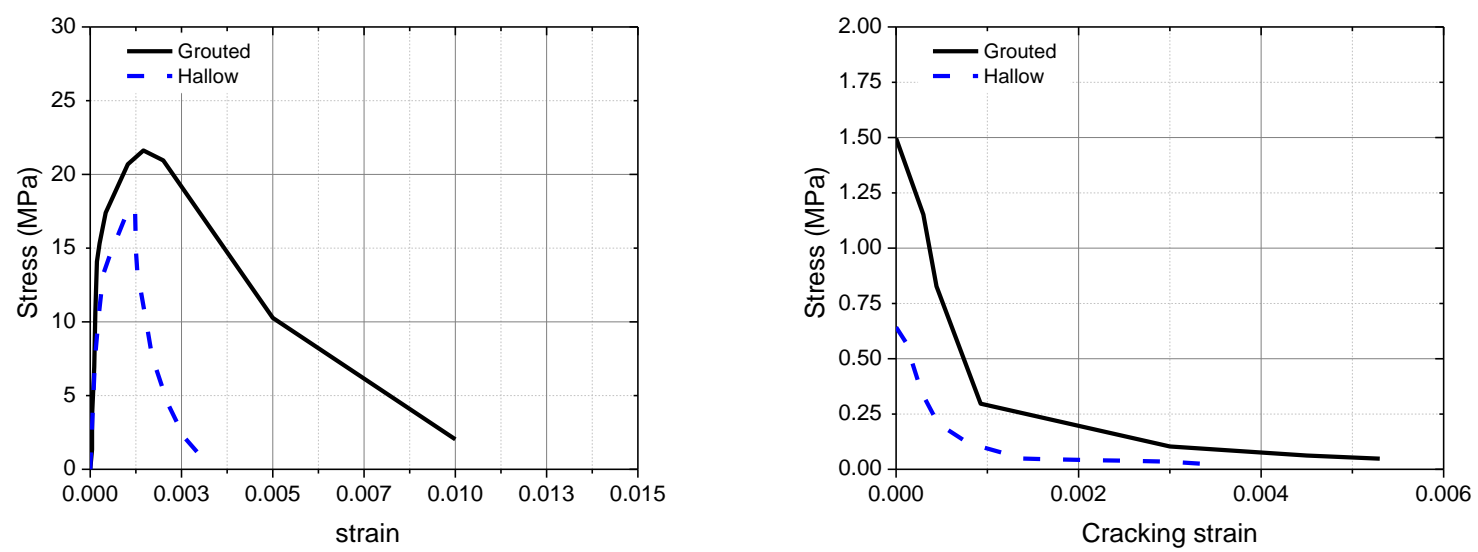

(a) Compressive behavior of prisms (b) Tensile behavior of tested assemblages

Fig. 21 Compressive and tensile behavior of model 
Cohesive surface-based element- Cohesive interactions are a function of displacement separation between the edges of potential cracks. They are appropriate to model the separation between two initially bonded surfaces and can be applied in situations where cracks are expected to propagate. In this model, cracks are restricted to develop along the layers at the head and bed-joints. The mechanical constitutive behavior of cohesive elements is defined using traction-separation constitutive model. Prior to damage, the cohesive behavior follows a linear traction-separation law and progressive degradation of the bond stiffness leads to the bond failure. Once a damage initiation in the interface element is met, damage will take place based on material damage factor.

The strength of mortar and grout as the only sources of strength between units was considered for defining the traction behavior of the model. Mortar is the only source of bond resistance against shear forces along the bed-joints in the hollow portions. Therefore, the compressive strength of mortar (12.6 MPa) was used for the cohesive behavior of hollow panels in the normal mode of fracture. However, for grouted specimens the compressive strength of grout (23.7 MPa) was used as a normal mode of masonry fracture.

Similarly, displacement of hollow and grouted diagonal tension at yield point and fracture were also used to define the separation behavior of elements. The yield and fracture displacement of hollow diagonal assemblages are 0.035 and $0.08 \mathrm{~mm}$, respectively. However, 0.045 and $0.09 \mathrm{~mm}$ were measured for the yield and failure displacement of grouted assemblages. By combination of these parameters the tractionseparation behavior of interfaces element was defined for the model.

Shear strength of hollow and grouted assemblages ( 0.21 and $0.6 \mathrm{MPa})$ were also used for the shear mode parameter by defining the shear behavior of hollow and grouted assemblages as can be seen from Fig. 22. 


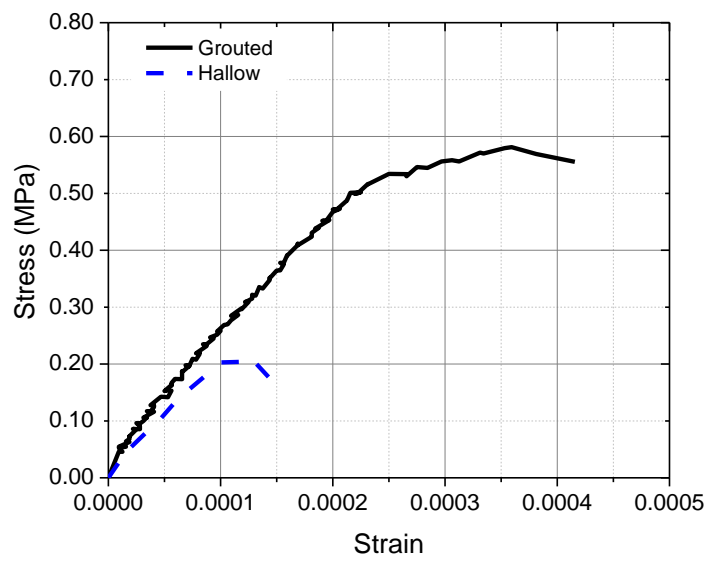

Fig. 22 Shear behavior of hollow and grouted assemblages

Cohesive elements are used to bond two bodies and they degrade after applying load due to the tensile or shear deformation. As a result, after de-bonding the two bonded component come into a contact. This interaction between surfaces is described by Coulomb friction and the employed model characterizes the frictional behavior of contacts using a coefficient of friction of 0.78 .

Elastic-plastic model for steel and bed-joint reinforcement- Horizontal, vertical reinforcing bars and bed-joint reinforcements were modeled using elasticperfectly plastic model as shown in Fig. $23\left[F_{y}=414 \mathrm{MPa}\right.$ and modules of elasticity of 200 GPa]. Reinforcing bars were embedded into the grout and assumed to be smeared overly on crack without any sliding between them. Each rebar was defined based on its geometry dimensions using the simplified circular shape. It is assumed that there is no bond slip between the rebars and concrete.

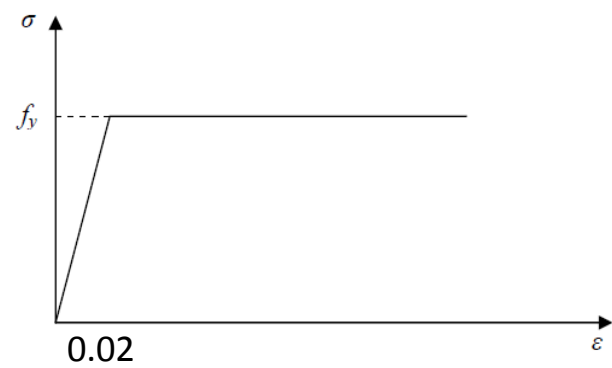

Fig. 23 Bilinear behavior for steel bar reinforcement 


\subsection{Geometry and boundary conditions}

The finite element mesh and boundary conditions of walls are shown in Fig. 24. Units are modeled using $203 \mathrm{~mm}$ cubical mesh. All models were tested under displacement control push-over analysis by applying displacement at the top of the specimen using Abaqus explicit. The use of higher order elements often results in extensive computation time and analysis without acquiring ideal accuracy into the overall analysis outputs. Due to a large number of elements an eight-node 3D stress linear brick, reduced integration elements (C3D8R) were used for modeling the masonry units. These elements are based on a $4 \times 4$ Gauss integration scheme with linear interpolation. The model adopts a constant shear strain over the elements area by considering a linear varying normal strain through the elements. The geometry of walls and defined interaction surfaces between units are shown in Fig. 25. The size of grouted piers and beams are 203X203 mm and 406X203 mm in the SR and DR walls. The thickness of mortar is considered zero in all specimens. The same dimensions of wall DR were used for building the model of wall DR-JR. The masonry block is modeled as a solid unit with equivalent thickness equal to the thicknesses of unit face-shells. Additionally, an elastic foundation using the same parameters of grout was considered in the models. Master and slave surfaces were defined in the bed and head joints between the units. The traction-separation behavior was assigned to the surface based cohesive behavior of mortars.

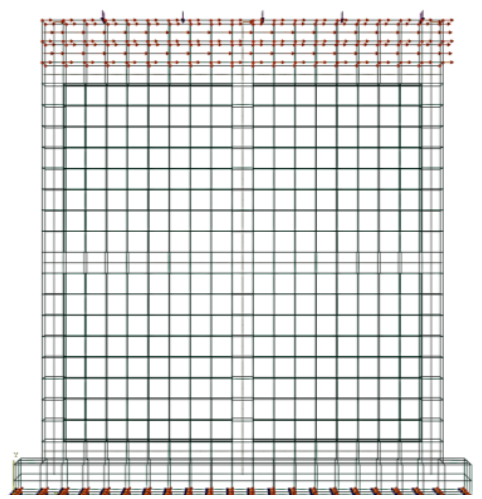

SR wall

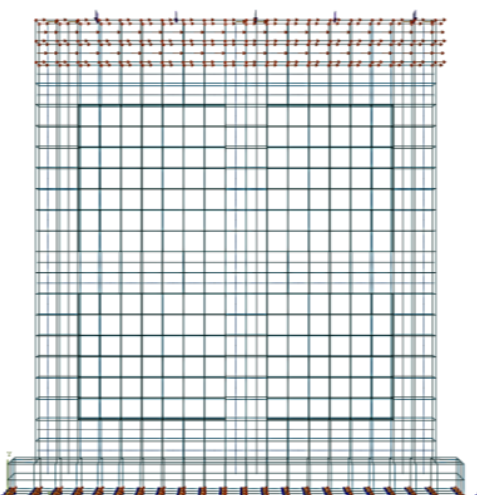

DR wall

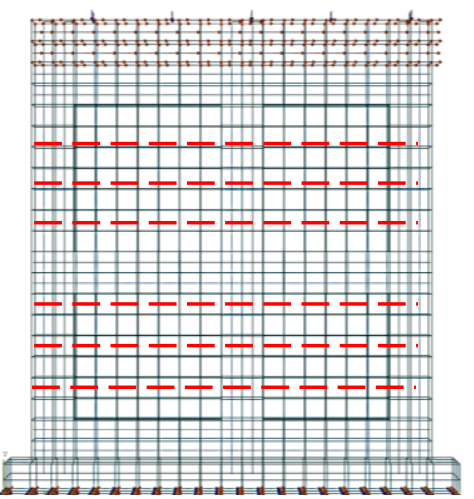

DR-JR wall

Fig. 24 Finite element mesh and boundary condition 


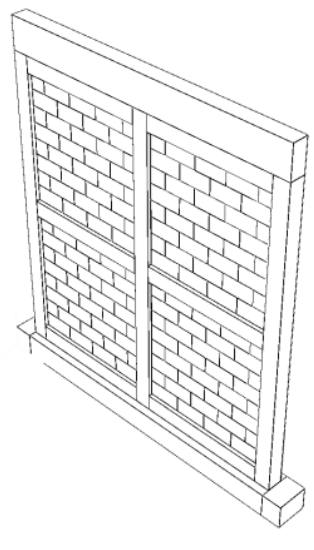

SR wall

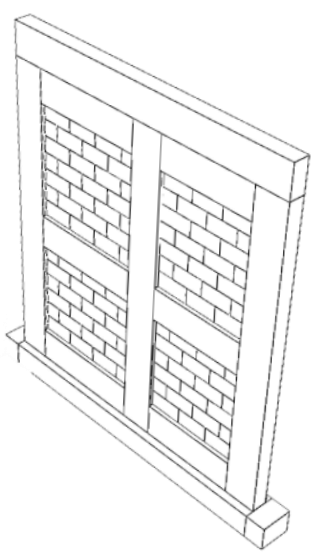

DR wall

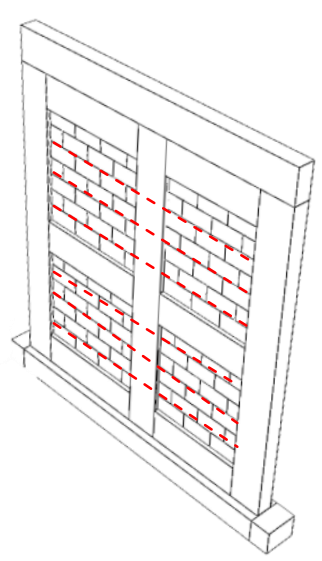

DR-JR wall

Fig. 25 Geometry of walls and surface-based interaction of units

\subsection{Further analytical case studies}

The proposed numerical model considered for the further analytical case studies to explore the effect of grouting, frame stiffness and confinement, on the wall response. Among the all possible scenarios two extra wall configurations were investigated using three (TR) and four side-by-side (QR) grouted cells. To keep the amount of reinforcement constant, the size of rebars were reduced to 2D 10 and 1D 13 in the triple and to $3 \mathrm{D} 10$ in quadruple cells grouted specimens.

\subsection{Correlation of experimental and numerical results}

The lateral load vs. lateral deformation curves obtained from the tests and analyses of SR, DR, and DR-JR walls are compared in Fig. 26. For having a better presentation of the walls behavior, the deformed mesh of walls at the maximum imposed drift of analysis in addition to the final crack pattern of walls are also plotted in the Fig. 26. As can be seen both the lateral strength and stiffness of SR wall obtained in the analysis are the same as those from the test. Despite the similar strength and stiffness, deformation capacity obtained from the analysis of wall SR is also the same as experimental values. 
Wall SR provides the best correlation between the numerical and test results. However, several distinctions can be observed by comparing the final crack pattern of wall SR obtained in the numerical modeling to the actual damage pattern from the test. First, the anti-symmetric crack pattern which indicates in the numerical model only monotonically increasing displacement is imposed on the wall. Second, the toe crushing was not observed in the numerical deformed mesh which alludes to the frame action. Although the same effect led to crushing in the toe of the wall in the test, frame action causes the cracks in the diagonal of hollow panels which is due to simplification of the model by considering the thin blocks.

Additionally, interlocking effect between frame and panels is not considered in the analysis which reduces the value of the load that the frame can take. Consequently, no crushing was obtained in the analysis since none of the blocks reached to the maximum strength. As described before, the failure mode of wall SR was dominated by shear and diagonal cracks were propagated in the hollow parts of specimens. Evidently, the final numerical crack pattern of wall SR shows the diagonal cracks in the hollow parts.

Proposed model was able to predict the strength and stiffness of DR and DR-JR walls as well. The stiffness and strength from the analysis of wall DR are slightly less than experimental results while both the stiffness and strength of wall DR-JR are higher than actual test values. This is dedicated to the presence of bed-joint reinforcements in the wall DR-JR. Horizontal tensile splitting and longitudinal cracks initiated at the top and bottom of bound beams were also captured in the numerical model of DR and DRJR walls. Although the numerical deformed mesh of these walls are not exactly the same as those obtained from the test, flexural cracks which are the resultant of doubly grouting the beams and piers, were observed as the main reasons of DR and DR-JR walls failure. 

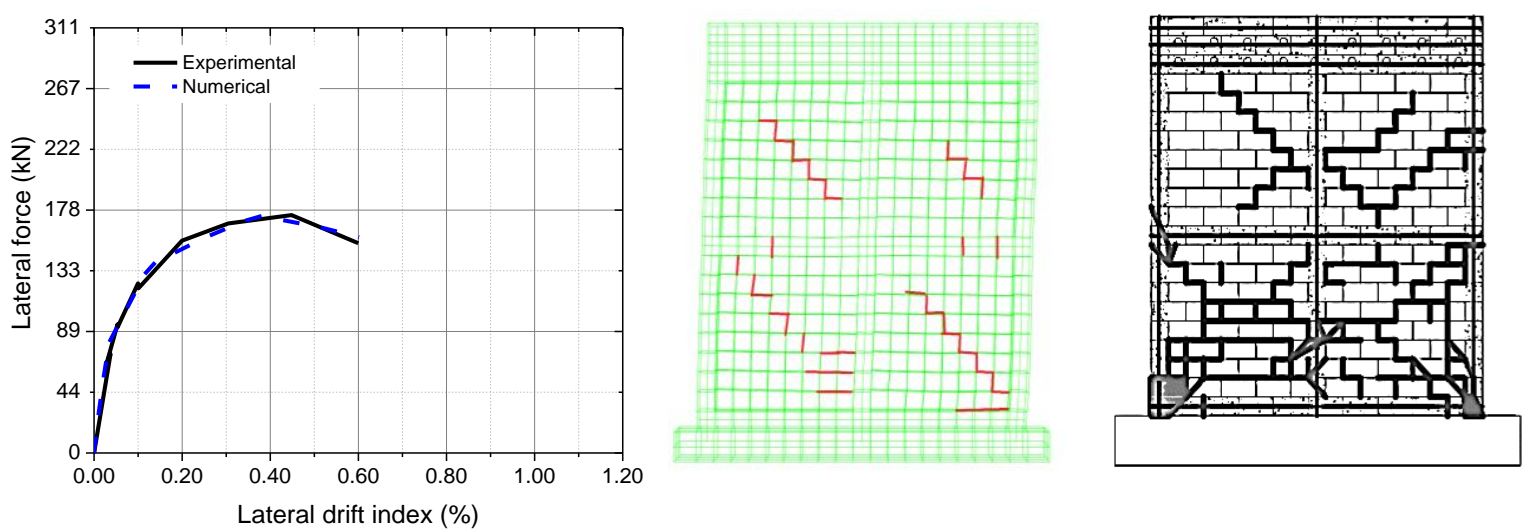

(a) SR wall
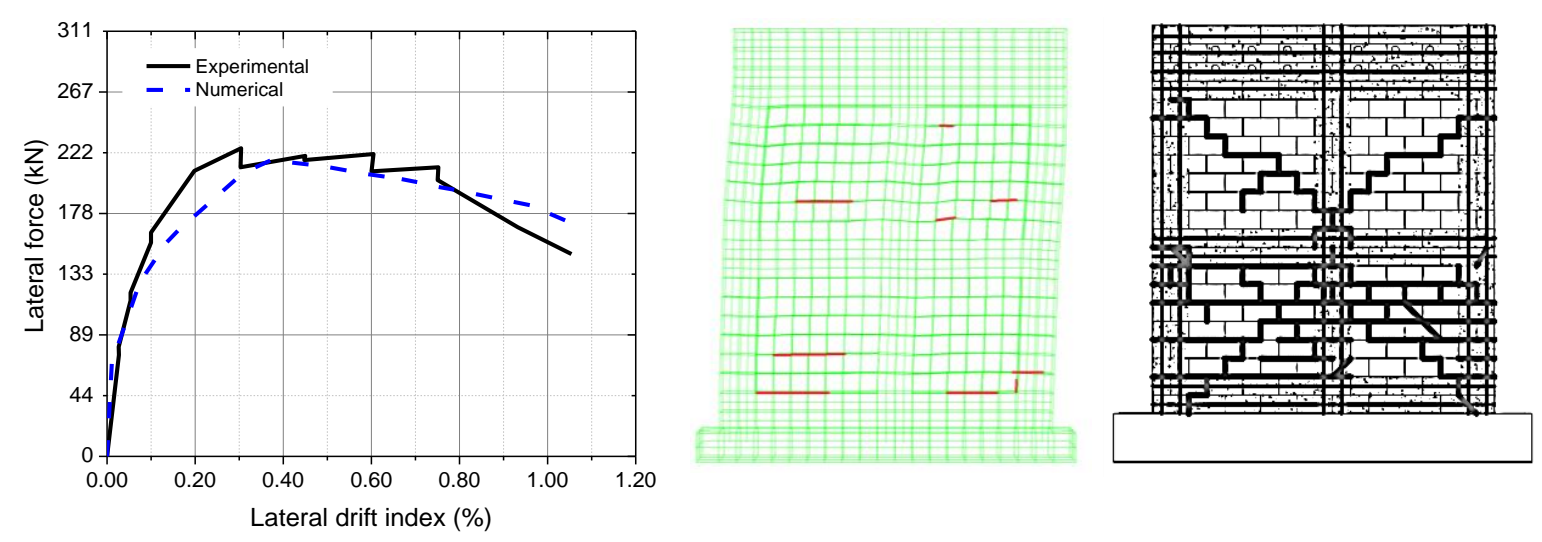

(b) DR wall
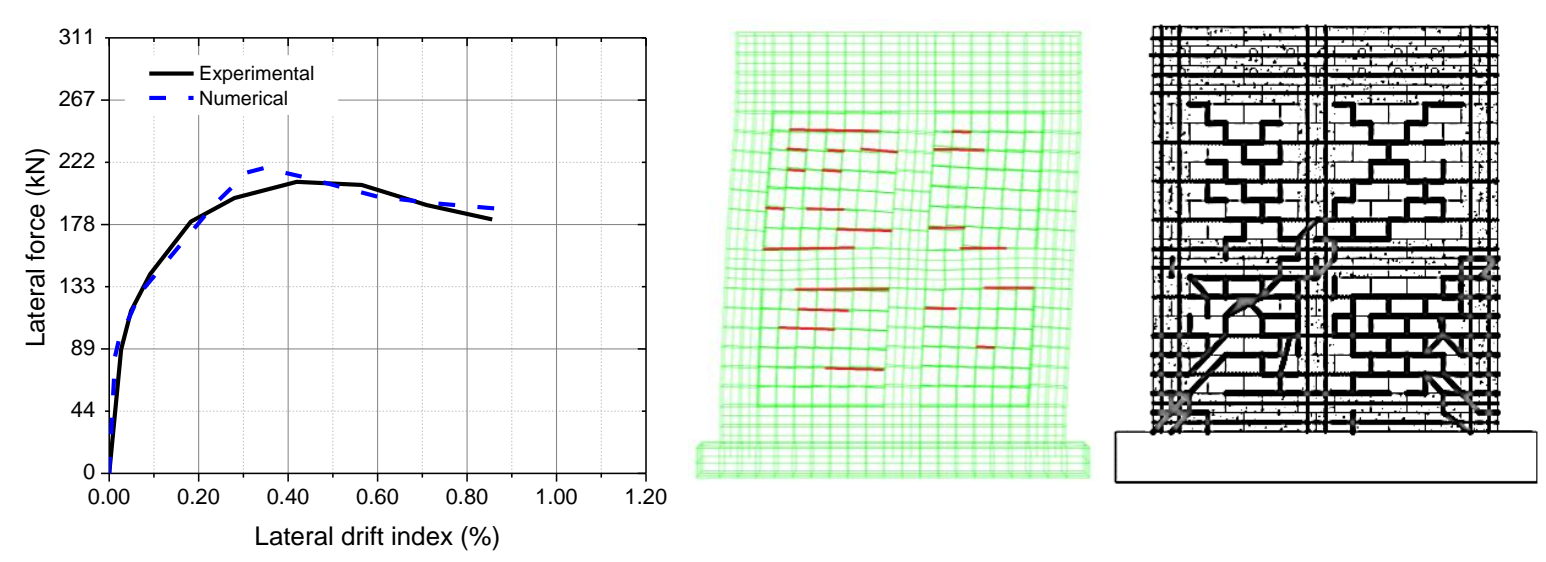

(c) DR-JR wall

Fig. 26 Load-deformation curves, numerical and experimental deformed shapes

Moreover, the number of cracks in the wall DR-JR (Fig. 26c) is obviously higher than wall DR which is the same as experimental results and bed-joint reinforcement 
resulted in controlling the crack width. After flexural cracks formed in the wall without bed-joint reinforcement, by increasing the lateral displacement cracks opened and the rest of hollow panel remained sound. This resulted in the small number of cracks, however distributed bed-joint reinforcement across the wall height enabled the distribution of stress in hollow panels. Accordingly, the initial cracks under the increased lateral displacement did not open significantly and new set of cracks spread throughout the wall.

\subsection{Numerical results}

Numerical lateral load-deformation of DR, TR and QR walls are plotted in Fig 27. Shear strength and deformability of both TR and QR walls increased compared to wall DR. As can be seen from Fig. 27, wall QR has the highest stiffness and shear strength compare with two other walls. Lateral load-deformation, Mises contour and deformed mesh of TR and QR walls are presented in Fig. 28.

Appling diagonal load to a bare hollow or grouted masonry panels results in an abrupt tensile failure initiated by a stepped crack [35]. Unconfined hollow or grouted masonry panels divide into two separate parts followed by collapse after crack propagates in the specimens (refer to Fig. 3). Opposed to the bare panel when a diagonal crack initiate within an infilled panel, panel can still carry load due to partial confinement that frame enforce to the panel. Grouting more adjacent cells altered the relative stiffness between the frame and infilled masonry. Relative stiffness increased as the number of grouted cells increased from wall DR to wall QR. The central strain of infill is not sensitive to the frame stiffness. However, the corners strain is highly affected by the frame stiffness [36]. Stress redistributed in the hollow panels instead of stress concentration at the edges that may cause local failure. Mises contour plotted in Fig. 28 are clearly showing this between two walls. A stiffer frame has a higher strength and also provides a better confinement for the surrounded infilled masonry. As a result, as shown in Fig. 7, the strength and ductility of walls increased as the number of grouted cells increased. 


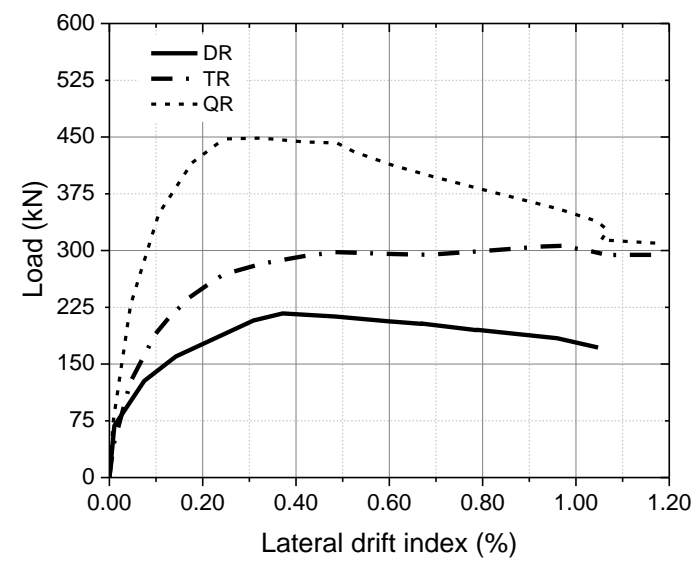

Fig. 27 Load-deformation curves
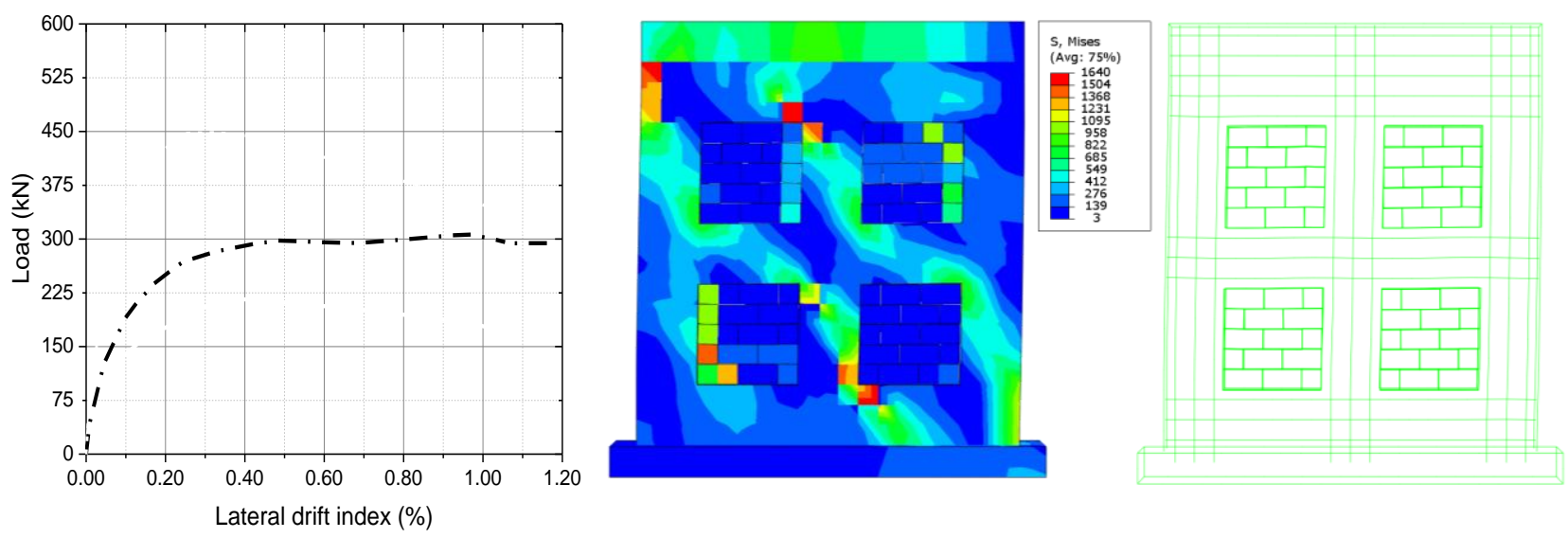

(a) TR
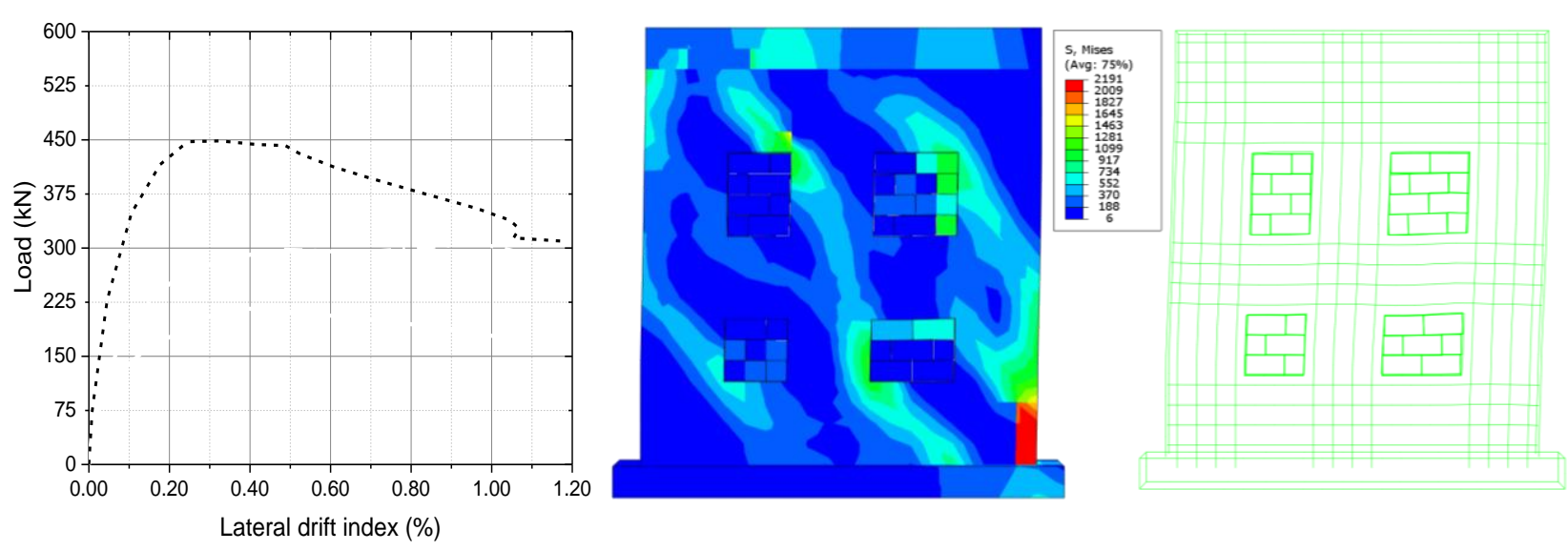

(b) QR

Fig. 28 Load-deformation curves, Mises contour and wall deformed shape 


\section{Summary and conclusions}

Three full-scale PG masonry shear walls; namely, single cell/bond beam reinforcing (SR), double cell/bond beam reinforcing (DR) and double cell/bond beam reinforcing with bed-joint reinforcement (DR-JR) were tested under constant axial compressive stress and increasing lateral top cyclic displacement. All specimens had approximately vertical reinforcement ratio of $0.1 \%$ of net area. However, horizontal reinforcement ratio of SR, DR and DR-JR walls were equal to $0.08 \%$ and $0.1 \%$, respectively. To explore the effect of grouting on the response of proposed wall configuration (doubly grouted) a numerical model was also conducted. Based on testing these three full-scale PG walls and also modeling two other walls using Abaqus, the following conclusions can be drawn:

-Using two reinforced and grouted cells/bond beams instead of one cell/bond beam resulted in a change of the failure mode from shear-dominated mode to a flexuraldominated mode. It also resulted in an increase the shear capacity and displacement ductility of walls by $34 \%$ and $47 \%$, respectively. Due to weak connection between piers and beams in the frame of wall SR, toes of the wall carry most of the load. As a result severe cracks formed in this zone and shear strength of the wall abruptly dropped. However, because of higher strength and deformability of grouted cells in wall DR, the load redistributed into the hollow panels and new set of cracks occurred across the wall. Therefore, combination of diagonal and horizontal cracks can be recognized in the final crack pattern.

-Wall with double reinforced cells/bond beams showed a $60 \%$ increase in elastic stiffness compared to the wall with single reinforcing cells. Wall DR exhibited flexurallydominating behavior, showing curveture ductility that is 40 percent higher than wall SR with single reinforcement that experienced a shear-dominating behavior. Additionally, wall SR showed larger damping factor at failure in comparison to wall with double reinforcing cells. 
-Although the horizontal steel ratio in DR-JR wall was almost 20 percent higher than DR wall, bed-joint reinforcement did not improve the strength and deformation capacity of partially grouted reinforced (double cells reinforcing) shear walls at the ultimate-limit state. However, bed-joint reinforcement resulted in controlling crack width at the serviceability limit-state. Increasing the lateral displacement of walls without bedjoint reinforcement, after diagonal cracks formed at top, existing cracks opened extensively and the rest of hollow panel remains sound. However, distributed bed-joint reinforcement across the wall height enabled the distribution of stress in hollow panels. Accordingly, the initial cracks under the increased lateral displacement did not open significantly and new set of cracks spread at the top of walls.

-It is evident from the numerical results that the responses predicted by the analysis are generally in agreement with the behavior of tested specimens. Numerical modeling also showed that the behavior of PG walls are similar to masonry infilled concrete frames. Additionally, the model showed that as the number of side-by-side grouted cells increases the shear strength and deformability of the wall increase. Grouting more adjacent cells altered the relative stiffness between the frame and infilled masonry. Stress redistributed in the hollow panels of the wall with a stiffer frame instead of stress concentration at the edges that may cause a local failure. A stiffer frame has a higher strength and also provides a better confinement for the surrounded infilled masonry. Therefore, the strength and ductility of walls increased as the number of grouted cells increased.

\section{Acknowledgments}

This project is supported by a grant from National Science Foundation (NSF) Grant No. 1208208. The authors would like to thank Dr. E. Minaie and Mr. G. Hilley for their dedication, help, and guidance. The support of Delaware Valley Masonry Institute and Sabia Mason Contractors in providing the mason to build the test specimens is acknowledged. The results, opinions, and conclusions expressed in this paper are 
solely those of the authors and do not necessarily reflect those of the sponsoring organizations.

\section{Nomenclature}

The following symbols are used in this paper:

$\mathrm{H}$ height of the wall $(\mathrm{mm})$;

$\mathrm{L}$ length of the wall $(\mathrm{mm})$;

$d_{y} \quad$ drift index of yielding point of displacement ductility curve;

$d_{u} \quad$ ultimate drift index for displacement ductility curve;

D damping factor

$\mu_{\Delta} \quad$ displacement ductility;

$\mathrm{w}^{+}$e positive triangle under maximum load of hysteric curve;

$\mathrm{w}_{\mathrm{e}}^{-}$negative triangle under minimum load of hysteric curve and,

$w_{d}$ area of cycles.

\section{References}

[1] Matsumura A. Shear strength of reinforced hollow unit masonry walls. In: proceeding of $4^{\text {th }}$ North American Masonry Conference; Los Angeles, California; 1987.

[2] Matsumura A. Shear strength of reinforced masonry walls. In: proceeding of the $9^{\text {th }}$ World Conference on Earthquake Engineering, Tokyo; 1988, pp. 121-126.

[3] Ghanem GM. Effect of steel distribution on the behavior of partially reinforced masonry shear walls. In: proceeding of $6^{\text {th }}$ Canadian Masonry Symposium, Univ. of Saskatchewan, Saskatoon, Sask., Canada; 1992, pp. 356-376.

[4] Ghanem GM, Salama AE, Elmagd SA, Hamid AA. Effect of axial compression on the behavior of partially reinforced masonry shear walls. In: proceeding of $6^{\text {th }}$ North American Masonry Conference (NAMC), Philadelphia; 1993, pp. 1145-1157.

[5] Schultz AE. Seismic resistance of partially grouted masonry shear walls. In: The Worldwide Advances in Structural Concrete and Masonry; 1996. 
[6] Ingham JM, Davidson B, Brammer D, Voon KC. Testing and codification of partially grout-filled nominally-reinforced concrete masonry subjected to in-plane cyclic loads. The Masonry Society Journal, 2001;19(1): 83-96.

[7] Voon KC, Ingham JM. Experimental in-plane shear strength investigation of reinforced concrete masonry walls. Journal of Structural Engineering, 2006;132(3):400-408.

[8] Minaie E, Mota M, Moon FL, Hamid AA. In-plane behavior of partially grouted reinforced concrete masonry shear walls. Journal of Structural Engineering, 2010;136(9):1089-1097.

[9] Bolhassani M, Hamid AA, Moon FL. Effect of axial load on the behavior of doubly reinforced partially grouted reinforced masonry shear walls. 12 North American Masonry Conference, Denver, Colorado; 17-21 May, 2015.

[10] Vanniamparambil PA, Bolhassani M, Carmi R, Khan F, Bartoli I, Moon FL, Hamid AA, Kontsos A. A data fusion approach for progressive damage quantification in reinforced concrete masonry walls. Smart Materials and Structures 23, no. 1 2014: 015007.

[11] Khan F, Rajaram S, Vanniamparambil PA, Bolhassani M, Hamid AA, Kontsos A, Bartoli I. Multi-sensing NDT for damage assessment of concrete masonry walls. Structural Control and Health Monitoring 22, no. 3, 2015: 449-462.

[12] Khan F, Bolhassani M, Kontsos A, Hamid AA, Bartoli I. Modeling and experimental implementation of infrared thermography on concrete masonry structures. Infrared Physics \& Technology, 69, 2015: 228-237.

[13] Foraboschi $P$, Vanin A. New methods for bonding FRP strips onto masonry structures: experimental results and analytical evaluations. Composites: Mechanics, Computations, Applications, An International Journal, 2013;4(1):1-23.

[14] Biolzi L, Ghittoni C, Fedele R, Rosati G. Experimental and theoretical issues in FRP-concrete bonding. Constr Build Mater, 2013;41:182-190.

[15] Hamed E, Rabinovitch O. Failure characteristics of FRP-strengthened masonry walls under out-of-plane loads. Engineering Structures, 2010;32(8),2134-2145.

[16] Foraboschi $P$. Strengthening of masonry arches with fiber-reinforced polymer strips. Journal of composites for construction, 2004;8(3),191-202.

[17] Schultz AE, Scolforo MJ. Overview of prestressed masonry. The Masonry Society Journal, 1991;10(1):6-21. 
[18] Yang KH, Joo DB, Sim Jl, Kang JH. In-plane seismic performance of unreinforced masonry walls strengthened with unbonded prestressed wire rope units. Engineering Structures, 2012;45:449-459.

[19] Ma R, Jiang L, He M, Fang C, Liang F. Experimental investigations on masonry structures using external prestressing techniques for improving seismic performance. Engineering Structures, 2012;42:297-307.

[20] Bolhassani M, Hamid AA, Moon FL. Enhancement of seismic performance of partially grouted reinforced masonry shear walls. 10th US National Conference on Earthquake Engineering, Anchorage, Alaska; July 21-25, 2014.

[21] Nolph S, ElGawady M. Static cyclic response of partially grouted masonry shear walls. Journal of Structural Engineering, 2012;138(7):864-879.

[22] Abaqus Analysis User's Manual. Dassault Systems Providence. RI, USA; 2013:6.13-3.

[23] Hamid AA, Bolhassani M, Turner A, Minaei E, Moon FL. Mechanical properties of ungrouted and grouted concrete masonry assemblages. $12^{\text {th }}$ Canadian Masonry Symposium, Vancouver, British Columbia; 2013.

[24] FEMA 356. Prestandard and commentary for the seismic rehabilitation of buildings. American Technical Council: Washington, DC, 2000.

[25] ACI 318 Committee. Building Code Requirements for Structural Concrete (ACI 31811) and Commentary. In American Concrete Institute, 2011;p. 503.

[26] Foraboschi P, Vanin A. Non-linear static analysis of masonry buildings based on a strut-and-tie modeling. Soil Dynamics and Earthquake Engineering, 2013;55:4458.

[27] Standards Association of New Zealand (SANZ). Design of reinforced concrete masonry structures. NZS 4230:2004, Wellington, New Zealand, 2004.

[28] SAP2000: integrated finite element analysis and design of structures. Analysis reference. Computers and Structures, 1997.

[29] Vanin A, Foraboschi P. In-plane behavior of perforated brick masonry walls. Materials and Structures, 2012;45(7):1019-1034.

[30] Foraboschi P. Coupling effect between masonry spandrels and piers. Materials and Structures, 2009;42(3):279-300.

[31] Biolzi L. Evaluation of compressive strength of masonry walls by limit analysis. Journal of Structural Engineering, 1988;114(10):2179-2189. 
[32] Lotfi HR, Shing PB. Interface model applied to fracture of masonry structures. Journal of Structural Engineering, 1994;120(1):63-80.

[33] Lotfi HR, Shing PB. An appraisal of smeared crack models for masonry shear wall analysis. Computers \& Structures, 1991;41(3):413-425.

[34] Kappos AJ, Penelis GG, Drakopoulos CG. Evaluation of simplified models for lateral load analysis of unreinforced masonry buildings. Journal of Structural Engineering, 2002;128(7):890-897.

[35] Bolhassani M, Hamid AA, Lau AC, Moon F. Simplified micro modeling of partially grouted masonry assemblages. Construction and Building Materials, 2015;83:159-173.

[36] Stafford-Smith B, Carter C. Method of analysis for infiled-frames. Proc. Inst. Civ. Eng., Struct. Build., 1969;44:31-48. 